\title{
Power Industry Restructuring and Eco-Efficiency Changes: A New Slacks-Based Model in Malmquist-Luenberger Index Measurement
}

\author{
Behrouz Arabi $^{\mathrm{a}^{*}}$, Susila Munisamy ${ }^{\mathrm{b}}$, Ali Emrouznejad ${ }^{\mathrm{c}}$, Foroogh Shadman $^{\mathrm{d}}$ \\ ${ }^{a}$ Institute of Graduate Studies, University of Malaya, Kuala Lumpur, Malaysia \\ ${ }^{\mathrm{b}}$ Faculty of Economics and Administration, University of Malaya, Kuala Lumpur, Malaysia \\ ${ }^{\mathrm{c}}$ Aston Business School, Aston University, Birmingham, UK \\ ${ }^{\mathrm{d}}$ Faculty of Engineering, University of Malaya(UM), Kuala Lumpur, Malaysia
}

\begin{abstract}
Measuring variations in efficiency and its extension, eco-efficiency, during a restructuring period in different industries has always been a point of interest for regulators and policy makers. This paper assesses the impacts of restructuring of procurement in the Iranian power industry on the performance of power plants. We introduce a new slacks-based model for MalmquistLuenberger (ML) Index measurement and apply it to the power plants to calculate the efficiency, eco-efficiency, and technological changes over the 8-year period (2003-2010) of restructuring in the power industry. The results reveal that although the restructuring had different effects on the individual power plants, the overall growth in the eco-efficiency of the sector was mainly due to advances in pure technology. We also assess the correlation between efficiency and ecoefficiency of the power plants, which indicates a close relationship between these two steps, thus lending support to the incorporation of environmental factors in efficiency analysis.
\end{abstract}

\section{Keywords}

Eco-Efficiency Measurement, Data Envelopment Analysis, Malmquist-Luenberger Index

\footnotetext{
${ }^{*}$ Corresponding Author: Address: Room No. B28, Faculty of Economics and Administration Building, University of Malaya, 50603 Kuala Lumpur, MALAYSIA, Tel: 006017-6481918, Email: beh.arabi@gmail.com
} 


\section{Introduction}

In the contemporary era, the lack of resources has necessitated a general approach to the sustainable development. This has led many organizations to be more mindful of consumption and waste production, and to employ more subtle performance measurement systems. In line with this, environmental management and protection play a critical role. In environmental protection, less input consumption and waste production as well as green products, i.e. products that are compatible with nature, are the most significant issues. Furthermore, to be compatible with the national and international laws and protocols, and the organisational objectives, any organisation that strives for sustainable development has to measure its economic as well as environmental efficiency (Hasna, 2007). Therefore, incorporating unwanted by-products such as waste has become a common approach in the majority of performance measurement systems and researches.

Nonetheless, private organisations are not the only responsible parties in sustainable development, as governments, too, play a major role (Bennett et al., 2004). In many countries, the majority of public sector industries are either controlled or owned by the government. Thus, governments are not just responsible for the surveillance of such industries, but have to control them as owner and manager and be responsible to nongovernmental organizations (NGOs) with respect to sustainable development (Kim, 2004). It is the governments' duty to report on the endeavours that have been made to ensure security, quality, and continuity (SQC) of the services and to make sure that these services are sustainable.

Among all public sector industries ${ }^{1}$, the power generation industry has a pivotal role to play, as it

\footnotetext{
${ }^{1}$ As long as the electricity industry is owned and managed by government, it is enumerated in public sector
} 
is not just a consumer of energy resources but also a producer of energy at the same time. According to the key world energy statistics as reported by the International Energy Agency (IEA) in 2012, power plants consumed 55\%, 1\%, and 26\% of produced coal, petroleum, and natural gas in 2010. According to this report, 19\% of the energy in the world was consumed by power generation industries in 2010. That is while in 2010 the share of electricity in the overall global energy supply was only $17.7 \%$.

The power industry is responsible for electricity supply in all countries, and its duties fall into four main categories: generation, transmission, distribution, and retailing. The independent power producers (IPPs), i.e. power plants, are suppliers of the power market. In the last three decades, many countries have followed the UK's experiences in power industry to reform and restructure their power industry (Stagliano, 1997). According to Ghazizadeh et al. (2007) and Eybalin and Shahidehpour (2003), the increase in productivity, capital absorption, transpiration of interactions, sustainability, compliance with the international rules and regulations, stabilisation, and public ownership extension are the main goals of restructuring in the power market establishment (Hansen, 1996; Kern and Smith, 2008). The increased concern among regulators and policy makers about reaching these goals has led to the importance of measuring performance of the newly established markets (Walls et al., 2007). Hence, each power market regulator, similar to other market regulators, has to measure power plants' efficiencies or ecological efficiencies by including environmental factors, for successfully operating in the power market and plan for sustainable development (Sharabaroff et al., 2009). Towards this end, many performance measurement methodologies have been adjusted to incorporate the industries. 
aforementioned environmental concerns.

By standard definition, efficiency is the ratio of good outputs to resources used (Koopmans, 1951). Although it is common in production processes, some production processes may also generate undesirable outputs; in this case, desirable and undesirable factors should be treated differently. In the literature, many kinds of undesirable factors are reported, but our focus is mainly on emissions such as $\mathrm{SO}_{2}, \mathrm{NO}_{\mathrm{x}}$, and $\mathrm{CO}_{2}$ gases (Burnett and Hansen, 2008; Korhonen and Luptacik, 2004; Oggioni et al., 2011; Oude Lansink and Bezlepkin, 2003; Tyteca, 1997; Zaim and Taskin, 2000; Zhou et al., 2007). $\mathrm{SO}_{2}$ is the main cause of acid rains, which destroy jungles, farms, and even the soil. Exposure to $\mathrm{SO}_{2}$ can be harmful for humans as it can lead to respiratory problems such as asthmatic diseases. ${ }^{2}$ For these reasons, industries try to streamline their production by taking into account emissions as well as consumption control. $\mathrm{NO}_{\mathrm{x}}$ pollutants are also one of the major sources of acid rains, which can eventually result in global warming. Exposure to $\mathrm{NO}_{\mathrm{x}}$ gases can cause respiratory and neurological problems. $\mathrm{CO}_{2}$ is one of the main causes of global warming and consequently climate change. The economic management, when accompanied by environmental management, requires a special tool for performance measurement, which is known as eco-efficiency.

Many researchers have reported that the efficiency level can be held constant or improved even if undesirable outputs such as emission are incorporated in efficiency measurement methods (Korhonen and Luptacik, 2004). This is the key success factor for the eco-efficiency measurement studies. In order to conduct eco-efficiency measurement, many methods have been

\footnotetext{
${ }^{2}$ Agency for Toxic Substances and Disease Registry (ATSDR). 1998. Toxicological profile for Sulfur Dioxide. Atlanta, GA: U.S. Department of Health and Human Services, Public Health Service.
} 
used but data envelopment analysis (DEA) is one of the most popular ones.

DEA, which was inspired by Farrell's work (1957), was introduced by Charnes, Cooper, and Rhodes (1978) and soon the method, which is based on relative efficiency assessment, was applied in various fields for productivity and performance measurement. DEA was also employed to measure efficiency when undesirable factors are incorporated. Scheel (2001) categorised the incorporation of undesirable factors into direct and indirect approaches. The indirect approaches are those that change or customise undesirable factors to include them in the model. The direct approaches treat undesirable factors as the same amount but modify the measurement model. There are a handful of indirect approaches such as using the additive inverse of undesirable factors (Berg et al., 1992), treating the undesirable output as an input (Tyteca, 1997), and using multiplicative inverse (Knox Lovell et al., 1995). The common models in the direct approaches are hyperbolic efficiency model (Boyd and McClelland, 1999), slacksbased measure (SBM) (Tone, 2001), range adjusted measure (RAM) (Zhou et al., 2006), with the most popular model being directional distance function (DDF) (Chung et al., 1997).

The DDF approach has had numerous applications until now (Färe and Grosskopf, 2010a; Färe et al., 2007; Picazo-Tadeo et al., 2005). In spite of its popularity, this approach uses arbitrary directions to project the DMU to the frontier, which may not necessarily be the best direction. In this paper, based on Färe and Grosskopf (2010a, 2010b), we introduce a slacks-based measure to incorporate undesirable outputs. This new model does not deploy arbitrary directions but puts the DMU in the best light by finding an optimal direction. We have discussed restructuring in the power industry and the needs for observing the key success factors pertaining to eco-efficiency improvements. This paper will apply the proposed model to the Iranian power generation industry to measure the efficiency, eco-efficiency, and technological changes over the period 
(2003-2010) of restructuring in Iran’s power industry.

The rest of the paper is organised as follows: Section 2 gives an overview of power industry restructuring in different countries as well as in Iran. An overview of environmental issues of power generation industry in Iran is given in Section 3. Section 4 reviews efficiency and ecoefficiency definitions and various measurement methods as well as important measurement factors in power generation industry. In Section 5, literatures related to DDF models and ML index are reviewed. The new slacks-based model for ML index is also introduced in this section. Section 6 provides full discussion with an application of the new proposed model on both efficiency and eco-efficiency changes in a set of power plants in Iran. Section 7 concludes the paper and gives some topics for future research in this area.

\section{Power industry restructuring and its requirements}

Over the last two decades, power industries around the world have witnessed regulatory reform and restructuring. The United Kingdom was probably the first country to experience power industry reform and restructuring in the early 1990s (Stagliano, 1997), which was then followed by other countries such as the United States (Cronin and Motluk, 2006; Wiser et al., 1998), Scandinavian countries (Viljainen and Partanen, 2005), South American countries such as Argentina, Brazil, and Chile (Rudnick et al., 2005), and many others. The common experience in all these countries is that power industry restructuring can lead to better services, technological improvements, improved reliability, and reduction in customer costs (Khosroshahi et al., 2009). More recently, Turkey has also shown a brilliant record in reaching the supposed objectives as 
well as improving the important factors of power industry restructuring ${ }^{3}$ (Bulent Tor and Shahidehpour, 2005; Tor, 2005).

The Iranian government initiated preliminary studies of restructuring in the early 1990s. The privatisation of power plants, vertical unbundling of power generation, transmission, distribution, and retail trading, financial, and accounting separation, and inauguration of the power market followed suit. (Khosroshahi et al., 2009). According to Ghazizadeh et al. (2007, p. 1), the electricity sector leaders and planners who initiated the reforms had the following two objectives in mind:

a. "It is expected that the restructuring and consequently the privatisation would improve the performance and efficiency of the present industry"; and

b. "It is expected that the development of a new competitive paradigm in the electricity industry could make the sector more attractive for potential independent investors.”

In the fourth and fifth development plans, ${ }^{4}$ there is a shift toward sustainable development as concerns about awareness of environmental issues increased. The leaders and planners’ agenda are to uphold environmental protection while restructuring the power market. This is supported not only by national laws but also by power industry and power market rules and regulations.

\footnotetext{
3 Turkey has considered several important factors in their power industry reform plan such as promotion of generating capacity, privatisation, long-term contracts, liberalisation of electricity prices, energy quality and security, technical and non-technical losses, increase in the reliance on natural gas, environmental issues and renewable energy, and need for qualified staff and expertise (Bulent Tor and Shahidehpour, 2005; Tor, 2005)

${ }^{4}$ Iran has initiated development plans from 1988 which are passed as laws every five years to conduct the overall rebuilding and developing the country after an 8-year war against Iraq
} 
The focus of different power industry sectors in Iran has been on power generation, power market inauguration, and privatisation, which initiated with the power generation sector.

\section{Environmental issues of power generation industry}

In recent years, there has been an increasing focus on the electricity generation sector by the energy regulator. This is because of the rising concerns about the environmental issues and the policies developed to improve incentives to generation plants to reduce their emissions. The electricity generation industry accounted for $36.7 \%, 31.8 \%$, and $29.1 \%$ of $\mathrm{CO}_{2}, \mathrm{NO}_{\mathrm{x}}$, and $\mathrm{SO}_{2}$ emissions in Iran in 2010 (Iran Energy Balance Sheet Report 2010). ${ }^{5}$ This shows that the power generation industry is responsible for a big part of the emissions in the country. Therefore, the government ratified a number of laws and regulations to curb the emissions. Article 15 of air pollution prevention law ${ }^{6}$ determines the maximum amount of emissions allowed to be produced by the power plants. Then, in the third national development plan law, Article 121 (2000) was validated and included in the fourth national development plan law. Next, Article 20 (2004) which requires major reductions in fuel consumption and emission, through all possible means, is emphasised. Many rules and regulations were passed or modified to fulfil the requirements of the third and fourth national development plans.

These rules and regulations applied to different fields such as optimisation of energy generation, transmission, distribution, and consumption facilities. Energy pricing and charges, standards of buildings, and even promotion of wind and hydroelectricity and other forms of renewable energy were addressed by the regulations. Recently, Iranian Ministry of Energy has issued net efficiency

\footnotetext{
${ }^{5}$ http://pep.moe.gov.ir/

${ }^{6}$ Air Pollution Prevention Law, for emission standards of factories and workshops passed in the year 2003.
} 
criteria for fossil fuel power plants and combined heat and power (CHP) systems to set the standards for fuel consumption and emission production of thermal energy generation facilities. It was realised that to promote the use of more renewable energy resources, ${ }^{7}$ the power generation companies should be provided with more incentives. In line with this, green electricity generation is supported by a number of incentives such as the power sector's license issuing and payment regulations (Ghazizadeh et al., 2007; Khosroshahi et al., 2009). By promoting wind and hydroelectricity and other forms of renewable energy such as wind, photocells, and biomass, e.g. it is predicted that the level of emission can be controlled by the end of the country's 20-year (2005-2025) vision plan (Mazandarani et al., 2011). They have shown that, although power plants’ nominal capacity will increase by about 215\% from 2010 to 2025, emissions will grow by about $150 \%, 226 \%$, and $175 \%$ by three different scenarios. ${ }^{8}$

From another perspective, improving power generation efficiency with controlled emission is of prime importance to power authorities and planners to help set an economic level of emission.

The next section is a review of literature on power plants efficiency and eco-efficiency in addition to the definitions of the power plants efficiency and eco-efficiency; related input and output factors are also addressed.

\footnotetext{
${ }^{7}$ Sunlight, wind, rain, tides, waves, and geothermal heat are called renewable energy sources. Hydroelectricity and biomass can also be enumerated as renewable energies.

${ }^{8}$ As indicated in Mazandarani et al. (2011) the three Scenarios are:

- Scenario 1: power plant composition in the future forecast based on the government policies to develop different type of power plants, so in this scenario, composition of different types of power plants nominal capacities would be different from now.

- Scenario 2: old composition has been designed to treat future development based on current composition of different type of power plant nominal capacity, so emission increase rate will be the same as nominal capacity growth rate.

- Scenario 3: fuel switching predicts the trend using the new policies for using alternative fuels for power plants.
} 


\section{Iran power plants efficiency and eco-efficiency measurement}

\section{Power plants efficiency and eco-efficiency measurement using DEA}

One of the earliest researches that chose DEA as the main methodology to evaluate the efficiency of power plants was a project undertaken by Golany et al. (1994). After that many experts used the valuable outcome and indices in the research by Golany et al. and deployed DEA models to evaluate relative efficiencies of power plants in different countries (Athanassopoulos et al., 1999; Chitkara, 1999; Goto and Tsutsui, 1998; Jha and Shrestha, 2006; Sarica and Or, 2007). More recently, one can also find a number of studies on power plant ecoefficiency measurement in the literature (Korhonen and Luptacik, 2004; Sueyoshi and Goto, 2011; Yang and Pollitt, 2009, 2010).

However, in recent decades, the monitoring or surveillance bodies in different countries, which are in charge of providing reports on performance of power plants for decision-making authorities, such as ministries of energy or power market regulators, have faced difficulties in providing such reports. This is because of the heterogeneous nature of power plants that makes comparison of different power plant types' complex (Korhonen and Luptacik, 2004; Walls et al., 2007). Nonetheless, this type of comparative analysis is critical for power industries due to the importance of budgeting and resource allocation for short-, mid-, and long-term planning. Thus, efficiency measurement with the same yardstick has always been critical for regulators in all power industries.

\section{Power plants efficiency and eco-efficiency measurement in Iran}

In Iran, as in other countries, in the early stages of evaluation just the 'yield factor' was used as the main performance measure to fulfill the common instructions of turbine producers and 
conditions set by the administration for preparing reports and receiving budgets for the operation, maintenance, and evolution. These types of reports are prepared for every turbine in power plants and are based on the technical measures available in the operation and maintenance manuals. However, academic research has been conducted on the power plant performance measurement in a parallel manner. There are a number of studies on the efficiency evaluation of power plants in Iran in scientific databases. ${ }^{9}$

Other than that, Azadeh et al. (2007) assessed the power generation system in Iran using neural network and PCA techniques and Alirezaee (2005) did a similar study using a partition-based algorithm. More recently, Azadeh et al. (2008, 2009) presented other studies in power plant performance evaluation using DEA. The majority of the researches in Iranian power sector used DEA as the measurement tool.

Several other related researches investigated the relationship between emissions produced by Iranian power plants with sustainable development in power industry, such as Mazandarani et al. (2010, 2011) and Karbassi et al. (2007).

In the following section, we will review the input-output specifications in previous studies before discussing the factors involved in eco-efficiency measurement.

\section{Input and output factors}

As introduced by Charnes et al. (1978) the ratio of outputs to inputs is used to measure the relative efficiency as formulated in DEA. Table 1 presents some of previous studies on DEA

\footnotetext{
${ }^{9}$ Some scientific articles have been published in Farsi which have not been cited here, those interested could refer to: http://www.civilica.com/
} 
efficiency of power plants, which can give useful ideas on the most appropriate factors to be utilised to model the efficiency of power plants. In this research, the focus is on thermal power plants and the models are run on three thermal power plant categories: steam, gas, and combined cycle. $^{10}$

\footnotetext{
${ }^{10}$ Normally a power plant, which uses steam, gas and coal-fired turbines, combined cycle, and diesel, is referred to as a thermal power plant. By steam and gas power plants, we refer to the power plants, which are using steam and gas-fired turbines to generate the electricity.
} 
Table 1: A summary of inputs and outputs incorporated in previous studies on efficiency/eco-efficiency evaluation of power plants using DEA

\begin{tabular}{|c|c|c|c|c|c|c|}
\hline No & Title & Author(s) & Year & Inputs & Outputs & $\begin{array}{c}\text { Capacity } \\
\text { as Capital? }\end{array}$ \\
\hline 1. & \begin{tabular}{|l|} 
Measuring efficiency of \\
power plants in Israel by \\
data envelopment analysis
\end{tabular} & $\begin{array}{l}\text { Golany, B. } \\
\text { Roll, Y. } \\
\text { Rybak, D. }\end{array}$ & (1994) & \begin{tabular}{|ll}
1. & Installed capacity \\
2. & Fuel consumption \\
3. & Manpower
\end{tabular} & \begin{tabular}{ll} 
Undesirable: \\
1. & $\mathrm{SO}_{2}$ emission \\
2. & Deviation from operational \\
\multicolumn{2}{c}{ parameters } \\
Desirable: \\
1. & Generated power \\
2. & Operational availability \\
\end{tabular} & Yes \\
\hline 2. & $\begin{array}{l}\text { Comparison of productive } \\
\text { and cost-efficiencies } \\
\text { among Japanese and US } \\
\text { electric utilities }\end{array}$ & $\begin{array}{l}\text { Goto, M. } \\
\text { Tsutsui, M. }\end{array}$ & (1998) & 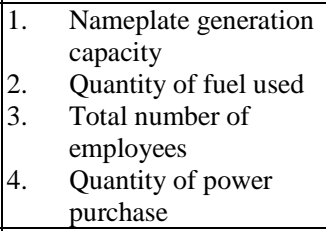 & $\begin{array}{ll}\text { Desirable: } \\
\text { 1. } & \text { Quantity sold to residential } \\
& \text { customers } \\
\text { 2. } & \text { Quantity sold to non-residential } \\
& \text { (commercial, industrial, others, and } \\
& \text { wholesale) customers }\end{array}$ & Yes \\
\hline 3. & \begin{tabular}{|l|} 
Data envelopment scenario \\
analysis for setting targets \\
to electricity generating \\
plants
\end{tabular} & $\begin{array}{l}\text { Athanassopoulos, } \\
\text { A.D. } \\
\text { Lambroukos, N. } \\
\text { Seiford, L. }\end{array}$ & (1999) & $\begin{array}{ll}\text { 1. } & \text { Fuel } \\
\text { 2. } & \text { Controllable costs } \\
\text { 3. } & \text { Capital expenditure }\end{array}$ & \begin{tabular}{ll}
\multicolumn{2}{l}{ Undesirable: } \\
$1 . \quad$ Generated pollution \\
2. & Accidents incurred \\
Desirable: \\
1. $\quad$ Electricity produced \\
2. $\quad$ Plant availability
\end{tabular} & No \\
\hline 4. & $\begin{array}{l}\text { Eco-efficiency analysis of } \\
\text { power plants: An } \\
\text { extension of data } \\
\text { envelopment analysis }\end{array}$ & $\begin{array}{l}\text { Korhonen, P.a J. } \\
\text { Luptacik, M. }\end{array}$ & (2004) & Total costs & \begin{tabular}{ll}
\multicolumn{2}{l}{ Undesirable: } \\
1. & DUST, \\
2. & $\mathrm{NO}_{\mathrm{x}}$ \\
3. & $\mathrm{SO}_{2}$ \\
Desirable: & \\
1. & Electricity generation \\
\end{tabular} & No \\
\hline 5. & $\begin{array}{l}\text { Characteristics of a } \\
\text { polluting technology: } \\
\text { Theory and practice }\end{array}$ & $\begin{array}{l}\text { Färe, R., } \\
\text { Grosskopf, Sh. } \\
\text { Noh, D-W, } \\
\text { Weber, W. } \\
\end{array}$ & (2005) & $\begin{array}{ll}\text { 1. } & \text { Labour } \\
2 . & \text { Installed capacity } \\
3 . & \text { Fuel }\end{array}$ & $\begin{array}{l}\text { Undesirable: } \\
\text { 1. } \quad \mathrm{SO}_{2} \text { emission } \\
\text { Desirable: } \\
\text { 1. } \quad \text { Generated power } \\
\end{array}$ & Yes \\
\hline 6. & \begin{tabular}{|l|} 
Efficiency assessment of \\
Turkish power plants using \\
data envelopment analysis
\end{tabular} & $\begin{array}{l}\text { Sarica, K. } \\
\text { Or, I. }\end{array}$ & (2007) & 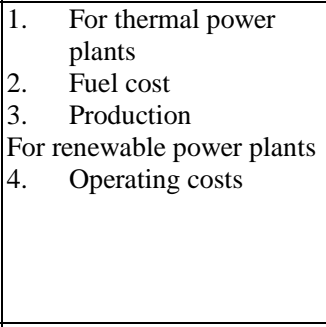 & 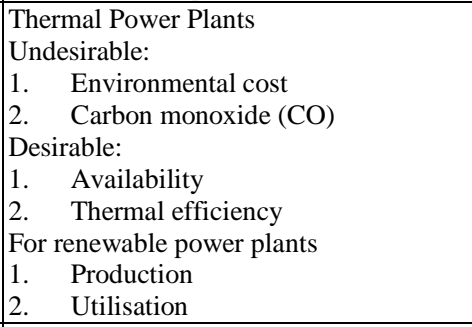 & No \\
\hline 7. & $\begin{array}{l}\text { Eco-efficiency: Defining a } \\
\text { role for environmental cost } \\
\text { management }\end{array}$ & $\begin{array}{l}\text { Burnett, R. D. } \\
\text { Hansen, D. R. }\end{array}$ & (2008) & $\begin{array}{ll}\text { 1. } & \text { Capital } \\
\text { 2. } & \text { Fuel costs } \\
\text { 3. } & \text { Operating costs }\end{array}$ & $\begin{array}{ll}\text { Undesirable: } \\
1 . & \mathrm{SO}_{2} \text { emission } \\
\text { 2. } & \text { Desirable: } \\
\text { 3. } & \text { Generated power } \\
\end{array}$ & Yes \\
\hline 8. & $\begin{array}{l}\text { DEA approach for unified } \\
\text { efficiency measurement: } \\
\text { Assessment of Japanese } \\
\text { fossil fuel power } \\
\text { generation }\end{array}$ & $\begin{array}{l}\text { Sueyoshi,T. } \\
\text { Goto, M. }\end{array}$ & (2011) & \begin{tabular}{|ll}
1. & Generation capacity \\
2. & Number of employees \\
3. & Coal \\
4. & Oil \\
5. & LNG \\
\end{tabular} & $\begin{array}{l}\text { Undesirable: } \\
1 . \quad \mathrm{CO}_{2} \text { emission } \\
\text { Desirable: } \\
\text { 1. } \quad \text { Generation }\end{array}$ & Yes \\
\hline
\end{tabular}

The 'Inputs' column in Table 1 shows that the majority of previous studies either proxied capital using installed capacity or altogether omitted it. We argue that installed capacity is not a proper surrogate for capital because it remains constant over years in most cases, while the power plant capital is affected by various factors such as depreciation, overhauls, and even its market value, which can cause yearly variations. To overcome this problem, Yaisawarng and Klein (1994) 
tried to simulate the capital by using the Handy-Whitman electric plant price index. However, the authors still used nameplate capacity and multiplied it by the cost of $1 \mathrm{KW}$ of installing capacity (which estimated as \$1973). By contrast, Shanmugam and Kulshreshtha (2005) introduced a different formula to estimate the capital, i.e., CAPITAL $=(S \times T) / 10,{ }^{3}$ where $S$ is the installed plant capacity in $M W$, and $T$ is the number of hours in a year. This measure is almost a linear function of the installed capacity as well. Therefore, in this study, we use effective capacity as a better proxy for the capital to derive a more precise evaluation of power plant efficiency. By definition, effective capacity is an empirical function of the aging factor, the temperature of the surroundings, and altitude. This factor is measured annually and renewed when a power plant gets its overhaul. Therefore, effective or operational capacity of a power plant can be a more accurate proxy for capital. ${ }^{11}$

Before we proceed further, it is important to address eco-efficiency definitions and discuss a central and contentious hypothesis about the relationship between efficiency and eco-efficiency.

\section{Eco-efficiency}

In many cases, it has been shown that cleaner production would be more efficient (Schaltegger et al., 2008). In addition, not only incorporating environmental factors can reduce the cost, but also -- it has been shown in many cases -- it can reduce the cost and environmental defects simultaneously (Burritt et al., 2004). Therefore, by including these new aspects and hypotheses we come up with a new type of efficiency dubbed ecological efficiency or briefly eco-efficiency. In Section 6, it is shown that in the case of thermal power plants in Iran, over an 8-year period of power industry restructuring, these hypotheses were found to be true.

${ }^{11}$ ISIRI 13375 1st. Edition http://www.isiri.org/Portal/Home/ 
Eco-efficiency concept stems from the definition of sustainable development. Brundtland (1987), who was the chairman of World Commission on Environment and Development, defined sustainable development as "to meet the needs of the present generation without compromising the ability of future generations to meet their own needs". Taking Kyoto Protocol ${ }^{12}$ to the United Nations Framework Convention on Climate Change into account, eco-efficiency claims that it is possible to be efficient or to increase the efficiency and maintain a certain level of environmental performance or improve it simultaneously ${ }^{13}$ (Jan et al., 1999).

A fractional definition that has four types of eco-efficiency has been established by Huppes and Ishikawa (2007). It is shown in Table 2:

Table 2: Four basic variants of eco-efficiency

\begin{tabular}{l|l|l}
\hline & Product or production prime & Environmental improvement prime \\
\hline Economy divided by environment & Environmental productivity & Environmental improvement cost \\
Environment divided by economy & Enit of environmental impact & $\begin{array}{l}\text { Cost per unit of environmental } \\
\text { improvement }\end{array}$ \\
\hline & $\begin{array}{l}\text { Environmental impact per unit of } \\
\text { production/consumption value }\end{array}$ & $\begin{array}{l}\text { Environmental improvement per unit } \\
\text { of cost }\end{array}$ \\
\hline
\end{tabular}

The above definitions pave the way for different industries to conduct numerous researches on the eco-efficiencies in their own interest areas, such as power plants (Korhonen and Luptacik, 2004), industrial system of a country (Zhang et al., 2008), farming (Picazo-Tadeo et al., 2011), eco-tourism, and world cement industry (Oggioni et al., 2011). Jasch (2004) defined comprehensive processes that are engaged in pollution and presented a comprehensive list of input and output measures of pollution.

\footnotetext{
${ }^{12}$ This is a protocol on reducing emission 5\% from the level of year 1990 to over a 5 years period from 2008 to 2012. http://unfccc.int/kyoto_protocol/items/2830.php

${ }^{13}$ STATE OF THE WORLD, 2008, Innovations for a Sustainable Economy, 25th Anniversary Edition
} 
In recent years, a number of researches have been conducted on eco-efficiency measurement using DEA (Burnett and Hansen, 2008; Korhonen and Luptacik, 2004; Welch and Barnum, 2009). The definition in the first row of Table 2, i.e., economy divided by environment, product, or production prim, is the definition considered in our research.

\section{ML index for eco-efficiency change measurement}

\section{A theoretical review}

Based on Malmquist index approach for efficiency and technology change, Chung et al. (1997) developed the Malmquist-Luenberger (ML) index. This index incorporates undesirable outputs in the evaluation of productivity change when a longitudinal study is conducted. In the same manner as Malmquist index, which is calculated using a series of DEA models (Färe et al., 1994), the ML index deploys directional distance function to solve four linear programming problems (LPs). These four LPs calculate distance functions to calculate technology and productivity change during the period of study. Towards this aim, Chung et al. (1997) defined $D$ as:

$$
D(x, y, b ; g)=\sup \{\theta:(y, b)+\theta g \in P(x)\},
$$

where $x \in \mathrm{P}^{I}, y \in \mathrm{P}^{J}$, and $b \in \mathrm{P}^{K}$ are inputs, outputs, and bad outputs of decision-making units (DMUs), respectively, and $\theta$ denotes the expansion proportion of good and contraction proportion of bad outputs, and $D$ expands them simultaneously as much as feasible. In equation (1), $I, J, K$ are the number of input variables, good output variables, and bad output variables, respectively. The directions vector is denoted by $g$ which is $g=\left(g_{y},-g_{b}\right)$, and production possibility set $P(x)$ is defined as: 


$$
P(x)=\{(y, b): x \text { can produce }(y, b)\}
$$

Färe et al. (2001) introduced the following model to measure the inefficiency of the DMUs using directional vector $g$ :

$$
D_{o}(x, y, b ; g)=\operatorname{Max} \theta
$$

Subject to

$$
\begin{aligned}
& \sum_{n=1}^{N} z_{n} x_{i n} \leq x_{i o} ; i=1,2, \ldots, I \\
& \sum_{n=1}^{N} z_{n} y_{j n} \geq y_{j o}+\theta g_{y} ; j=1,2, \ldots, J \\
& \sum_{n=1}^{N} z_{n} b_{k n}=b_{k o}-\theta g_{b} ; k=1,2, \ldots, K \\
& z_{n} \geq 0 ; g_{y} \geq 0 ; g_{b} \geq 0 ; \theta \geq 0 ; n=1,2, \ldots, N
\end{aligned}
$$

where $x_{i o}, y_{j o}$, and $b_{k o}$ are inputs, good and bad outputs corresponding to the under-assessment DMU, respectively, and $z_{n}$ are intensity variables. Chung et al. (1997) and (Färe et al., 2005) take $g=(y,-b)$ and $g=(1,-1)$ so that good outputs can be expanded while bad outputs are contracted simultaneously. Then Model (3) is deployed to calculate the ML productivity index in the longitudinal studies. In Model (3) inputs and good outputs obviously are free disposable, whereas together with good outputs, bad outputs are weakly disposable. If $\sum_{n=1}^{N} b_{k n}>0$ and $\sum_{k=1}^{K} b_{k n}>0$ are taken into account, the first inequality means at least one of the DMUs produces bad output and the other reflects that at least one of the bad outputs is produced by each DMU. These properties together with the null jointness property are mentioned in the last equality constraint of Model (3). ${ }^{14}$

However, DDF models (such as Model 3) usually use an arbitrary direction like $g=(y,-b)$ (Chung

\footnotetext{
${ }^{14}$ For the definitions of free and weak disposability and null jointness properties see Chung et al. (1997)
} 
et al. (1997)) or $g=(1,-1)$ (Färe et al., 2005), hence it undermines the accuracy of the efficiency measure derived. Since there is no guarantee that such directions project the inefficient DMU to the farthest point on the frontier and the benchmark shows the best target to the particular DMU among other possible points on the frontier. From this point onwards, we introduce two new models, which incorporate the best directions for this purpose to evaluate the efficiency or inefficiency score more accurately.

\section{A new slacks-based model for incorporating bad outputs}

One of the latest models, which was recently introduced by Färe and Grosskopf (2010a,b) is slacks-based model written as follows:

$$
D_{o}(x, y)=\operatorname{Max} \alpha_{1}+\cdots+\alpha_{I}+\beta_{1}+\cdots+\beta_{J}
$$

Subject to

$$
\begin{aligned}
& \sum_{n=1}^{N} z_{n} x_{i n} \leq x_{i o}-\alpha_{i} .1 ; i=1,2, \ldots, I \\
& \sum_{n=1}^{N} z_{n} y_{j n} \geq y_{j o}+\beta_{j} .1 ; j=1,2, \ldots, J \\
& z_{n} \geq 0 ; \gamma_{j} \geq 0 ; \beta_{i} \geq 0 ; n=1,2, \ldots, N ; j=1,2, \ldots, J
\end{aligned}
$$

In fact, Model (4) has been developed to find the best expansion and contraction rate for each output and input, respectively. The fact is that this model drives the DMU to the farthest point of the PPS by expanding the good outputs and contracting the bad ones simultaneously. However, it does not include bad outputs. Model (4) does not incorporate bad outputs; therefore, we adjust this model to obtain Model (5) below, which also includes bad outputs: 


$$
D_{o}(x, y, b)=\operatorname{Max} \beta_{1}+\cdots+\beta_{I}+\gamma_{1}+\cdots+\gamma_{K}
$$

Subject to

$$
\begin{aligned}
& \sum_{n=1}^{N} z_{n} x_{i n} \leq x_{i o} ; i=1,2, \ldots, I \\
& \sum_{n=1}^{N} z_{n} y_{j n} \geq y_{j o}+\beta_{j} .1 ; j=1,2, \ldots, J \\
& \sum_{n=1}^{N} z_{n} b_{k n}=b_{k o}-\gamma_{k} .1 ; k=1,2, \ldots, K \\
& z_{n} \geq 0 ; \gamma_{k} \geq 0 ; \beta_{j} \geq 0 ; n=1,2, \ldots, N ; j=1,2, \ldots, J ; k=1,2, \ldots, K
\end{aligned}
$$

Thus, according to Chung et al. (1997), the ML index can be calculated as follows:

$$
\begin{gathered}
M L E F F C H_{t}^{t+1}=\frac{\left(1+D_{o}^{t}\left(x^{t}, y^{t}, b^{t} ; y^{t},-b^{t}\right)\right)}{\left(1+D_{o}^{t+1}\left(x^{t+1}, y^{t+1}, b^{t+1} ; y^{t+1},-b^{t+1}\right)\right.} \\
M \operatorname{MTECH}_{t}^{t+1}=\left[\frac{\left(\left(1+D_{o}^{t+1}\left(x^{t}, y^{t}, b^{t} ; y^{t},-b^{t}\right)\right)\right.}{\left(\left(1+D_{o}^{t}\left(x^{t}, y^{t}, b^{t} ; y^{t},-b^{t}\right)\right)\right.} \frac{\left(\left(1+D_{o}^{t+1}\left(x^{t+1}, y^{t+1}, b^{t+1} ; y^{t+1},-b^{t+1}\right)\right)\right.}{\left(1+D_{o}^{t}\left(x^{t+1}, y^{t+1}, b^{t+1} ; y^{t+1},-b^{t+1}\right)\right)}\right]^{1 / 2} \\
M L_{t}^{t+1}=\operatorname{MECOEFFCH} H_{t}^{t+1} . M T E C H_{t}^{t+1} \\
M L_{t}^{t+1}=\left[\frac{\left(\left(1+D_{o}^{t}\left(x^{t}, y^{t}, b^{t} ; y^{t},-b^{t}\right)\right)\right.}{\left(\left(1+D_{o}^{t+1}\left(x^{t+1}, y^{t+1}, b^{t+1} ; y^{t+1},-b^{t+1}\right)\right)\right.} \frac{\left(\left(1+D_{o}^{t+1}\left(x^{t}, y^{t}, b^{t} ; y^{t},-b^{t}\right)\right)\right.}{\left(1+D_{o}^{t}\left(x^{t+1}, y^{t+1}, b^{t+1} ; y^{t+1},-b^{t+1}\right)\right)}\right]^{1 / 2}
\end{gathered}
$$

where $t=1 . . T$ denotes the periods of study. Phrasing in words, for example, represents the distance function for a DMU from period $t$ with respect to technology in period $t+1$. Consequently, the LPs corresponding to and are named mixed period models, since under evaluation DMUs and the frontier are from two subsequent periods.

From another perspective, Model (5) can be written as follows: 


$$
D^{\prime}(x, y, b)=\operatorname{Max} \beta
$$

Subject to

$$
\begin{aligned}
& \sum_{n=1}^{N} z_{n} x_{i n} \leq x_{i o} ; i=1,2, \ldots, I \\
& \sum_{n=1}^{N} z_{n} y_{j n} \geq y_{j o}+g_{y j} \cdot \beta ; j=1,2, \ldots, J \\
& \sum_{n=1}^{N} z_{n} b_{k n}=b_{k o}-g_{b k} \cdot \beta ; k=1,2, \ldots, K \\
& \sum_{j=1}^{J} g_{y j}+\sum_{k=1}^{K} g_{b k}=1 \\
& z_{n} \geq 0 ; \gamma_{k} \geq 0 ; \beta_{j} \geq 0 ; g_{y j} \geq 0 ; g_{b k} \geq 0 ; n=1,2, \ldots, N ; j=1,2, \ldots, J ; k=1,2, \ldots, K
\end{aligned}
$$

where $g_{y j}$ and $g_{b k}$ are entries of endogenous direction vector corresponding to the good and bad outputs respectively. Model (10) and Model (5) are equivalent. ${ }^{15}$ After running Model (5), using $g_{y j} \cdot \beta^{*}=\beta_{j}^{*}$ and $g_{y k} \cdot \beta^{*}=\gamma_{k}^{*}$ together with $\sum_{j=1}^{J} g_{y j}+\sum_{k=1}^{K} g_{b k}=1$ by solving a $J+K$ linearly independent equations with $J+K$ variable system of linear equations, we can find a unique solution, which is $\left(g_{y j},-g_{b k}\right)$ direction vector.

Model (10) is similar to Model (3) with the only exception that it has one more constraint of $\sum_{j=1}^{J} g_{y j}+\sum_{k=1}^{K} g_{b k}=1$. It is clear that this constraint does not change the production possibility set, $p(x)$, and the direction of the vector $\left(g_{y j},-g_{b k}\right)$ since the ratio of $g_{y j}$ 's to $g_{b k}$ 's remains unchanged here. Therefore, Model (10) inherits all properties of Model (3).

\section{Advantages of the new model}

Model (10) and its equivalent Model (5) introduce new advantages for eco-efficiency measurement using distance function models. First, as it was shown before, the direction is not chosen arbitrarily anymore and it is calculated endogenously. This is highly emphasised in non-

\footnotetext{
${ }^{15}$ This fact can easily be proven if we take $g_{y j} \cdot \beta=\beta_{j}$ and $g_{y k} \cdot \beta=\gamma_{k}$
} 
parametric methodologies such as DEA which rely more on actual data (Charnes, 1994; Yeh, 1996). Second, this endogenously calculated direction projects an inefficient DMU to the farthest point on the frontier (to find its peer or benchmark on the frontier), or in other words, the good and bad outputs can be expanded and contracted as much as possible at the same time. ${ }^{16}$ Hence, the advantage of the proposed model is that it lets the model decide about the direction, since $\left(g_{y j},-g_{b k}\right)$ are variables here (not parameters or arbitrarily chosen). As a result, $\beta$ will be maximized to consider the ratio of expanding the good outputs and contracting the bad outputs. In fact, this represents a more realistic inefficiency score for the DMUs, which are located below the efficiency frontier. This means that, Model (3) fails to find the best benchmark on the frontier to measure the under-assessment DMU's inefficiency score. Furthermore, although the model (10) is a non-linear mathematical programming model, its equivalent, Model (5), which is a linear model, can be employed instead for the computation purposes with more available solvers. Here we draw a simple example to illustrate Model (3), Model (5), and Model (10) and the related directions.

Table 3: A simple example, data and efficiencies

\begin{tabular}{|c|c|c|c|c|c|c|}
\hline & \multicolumn{2}{|c|}{ Data } & \multicolumn{2}{c|}{ Model 3 } & \multicolumn{2}{c|}{ Model 5 and 10} \\
\hline DMU & $\begin{array}{c}\text { Good } \\
\text { Outputs, } y\end{array}$ & $\begin{array}{c}\text { Bad } \\
\text { Outputs, } b\end{array}$ & $\begin{array}{c}\text { Inefficiency } \\
\text { Score }\end{array}$ & $g=\left(g_{y},-g_{b}\right)$ & $\begin{array}{c}\text { Inefficiency } \\
\text { Score }\end{array}$ & $g=\left(g_{y},-g_{b}\right)$ \\
\hline 1 & 4 & 3 & 0 & $(4,-3)$ & 0 & $(0.5,-0.5)$ \\
\hline 2 & 5 & 6 & 0 & $(5,-6)$ & 0 & $(0.5,-0.5)$ \\
\hline 3 & 3 & 5 & 0.35714 & $(3,-5)$ & 0.49999 & $(0.333,-0.667)$ \\
\hline
\end{tabular}

For the simplification purposes, all the input quantities, $x$, are taken as 1. A graphical

\footnotetext{
${ }^{16}$ In DEA, to find the efficiency or inefficiency rate, each inefficient DMU, which locates under efficient frontier is compared with a reciprocal (benchmark) on the frontier. By comparing the under assessment DMU with this benchmark, the model determines the efficiency or inefficiency score. Therefore, a realistic choice of the benchmark leads to a realistic rate of efficiency or inefficiency.
} 
presentation of DMUs in Table 3 is given in the following figure:

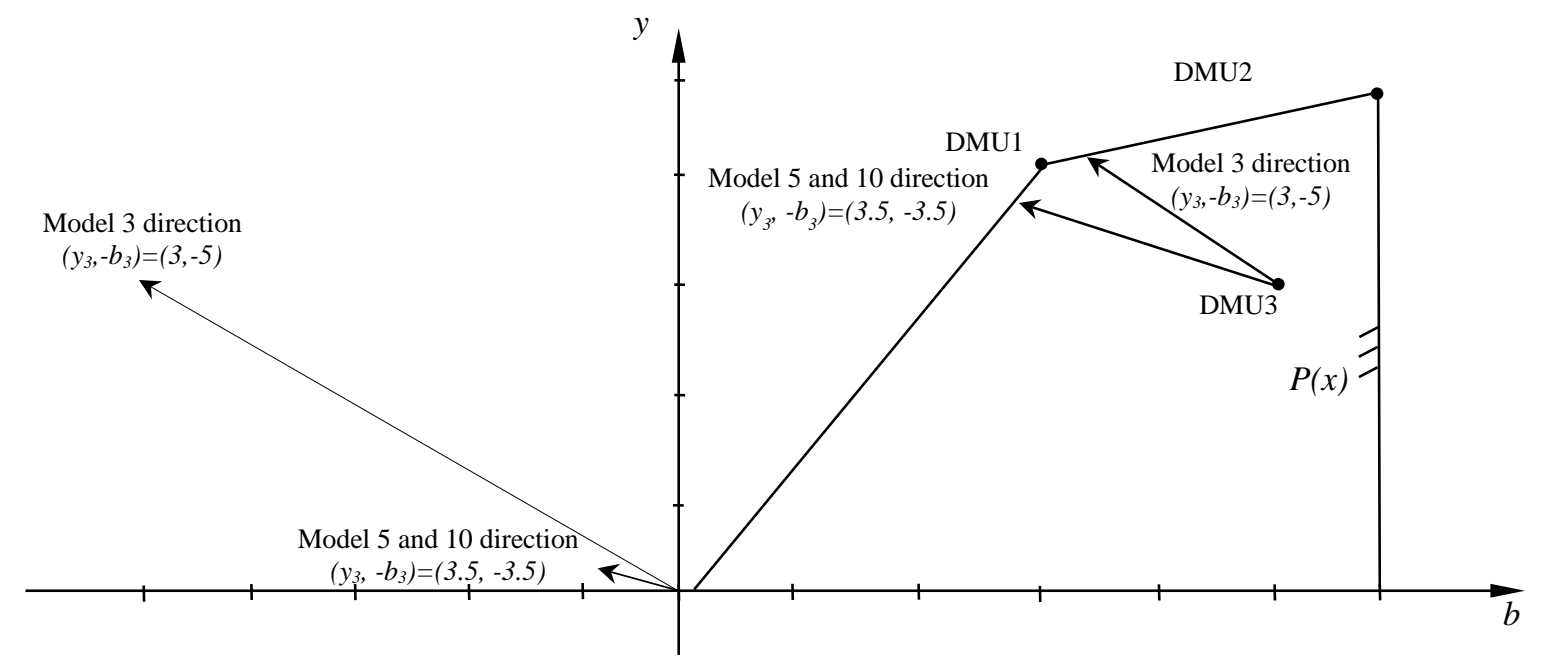

Figure 1: A graphical presentation of DMUs in Table 3

As can be seen in Table 3 and Figure 1, using Models (5) and (10), $\mathrm{DMU}_{3}$ has been projected to a farther point on the frontier; therefore the efficiency score of 0.49999 as calculated by Model (5) and Model (10) is relatively higher than 0.35714 that is calculated using Model (3).

Based on the above discussion, we employ Model (5) to evaluate the efficiency, eco-efficiency, and eco-efficiency change of Iranian thermal power plants during an 8-year period of power industry restructuring.

In the next section, the descriptive statistics of the data and the results are presented and discussed.

\section{Thermal power plants' eco-efficiency change in Iran}

\section{Data availability}

The input-output factors chosen to model the efficiency of thermal power plants in this study were based on Table 1, as well as on some other data not available to the public. The first input is 
effective capacity, which is a proxy for capital. Previous studies used installed or nameplate capacity in megawatts, which is the sum of all operational turbine capacities found in their operation manual catalogues. In this research, we deploy effective capacity instead of installed capacity. Effective capacity is defined as actual power of the power plants that can be generated by its turbines. ${ }^{17}$ The second input is fuel. Since a thermal turbine can consume different types of fuel (gasoline, gasoline, and fuel oil) and each fuel has different heating value, this factor is computed by the summation of the heat calories that each type of fuel can produce in a year. Generated power is the only desirable output employed for eco-efficiency measurement in this study. This factor is determined as the energy that has been engendered by a power plant and injected into the national power network in a year in megawatt hours. There are two undesirable outputs employed in this study. First, deviation from generation plan, which is calculated by the yearly summation of the declared available capacity minus actual energy generated during the daily peak hour in megawatt hours. The data for deviation from generation plan were submitted from the Iran National Dispatching Centre. Lastly, there is another undesirable output deployed in this subject area, which is $\mathrm{SO} 2, \mathrm{NOx}$ and $\mathrm{CO} 2$ emissions. This factor is calculated by tones of emission produced by a power plant in a year. The data for this factor was obtained from the TAVANIR $^{18}$ environment bureau. A brief descriptive analysis of the data is presented in Error! Reference source not found.. Note that each reference year begins on $21^{\text {st }}$ March and ends on

17 The data for effective capacity, fuel consumption, and generated power were retrieved from: http://www.tavanir.org.ir/

18 Iran Generation, Transmission, and Distribution Holding Company ${ }^{19}$ A kernel density plot helps making inferences about a finite data sample. This plot simply depicts the distribution pattern of a data sample around its mean. 
$20^{\text {th }}$ March, which are the first and the last days, respectively, in the Iranian calendar.

Table 4: Descriptive Statistics of the Power Plants' Input / Output Factors

\begin{tabular}{|c|c|c|c|c|c|c|}
\hline $\begin{array}{c}\text { Power } \\
\text { Plant } \\
\text { Technology }\end{array}$ & & Average & $\begin{array}{l}\text { Standard } \\
\text { Deviation }\end{array}$ & Variance & $\min$ & $\max$ \\
\hline \multirow{5}{*}{ Steam } & Effective Capacity (MW) & 772 & 559 & 312952 & 40 & 1843 \\
\hline & Fuel (Kilo Calorie) & 1. $E+10$ & $8 . E+09$ & $6 . E+19$ & $8 . E+08$ & $3 . E+10$ \\
\hline & Deviation From Generation plan (MWH) & 271 & 175 & 30594 & 42 & 904 \\
\hline & Emission (Tones) & 3144507 & $2 . E+06$ & $5 . E+12$ & 215662 & 7976671 \\
\hline & Generated Power(MWH) & $4 . E+06$ & $3 . E+06$ & 1.E+13 & 189702 & 11570097 \\
\hline \multirow{5}{*}{ Gas } & Effective Capacity (MW) & 321 & 402 & 161874 & 31 & 1640 \\
\hline & Fuel (Kilo Calorie) & 4.E+09 & $5 . E+09$ & $3 . E+19$ & 7.E+07 & 2. $E+10$ \\
\hline & Deviation From Generation plan (MWH) & 577 & 599 & 358391 & 42 & 4003 \\
\hline & Emission (Tones) & 1161810 & 1.E+06 & 2.E+12 & 19095 & 5189910 \\
\hline & Generated Power(MWH) & 1478368 & 2.E+06 & 4. $E+12$ & 8448 & 8977154 \\
\hline \multirow{5}{*}{$\begin{array}{l}\text { Combined } \\
\text { Cycle }\end{array}$} & Effective Capacity (MW) & 749 & 353 & 124381 & 203 & 1640 \\
\hline & Fuel (Kilo Calorie) & $9 . E+09$ & 4.E+09 & $1 . E+19$ & $3 . E+09$ & 2. $E+10$ \\
\hline & Deviation From Generation plan (MWH) & 484 & 255 & 65048 & 79 & 1222 \\
\hline & Emission (Tones) & 2511725 & 1.E+06 & 1.E+12 & 798328 & 4741725 \\
\hline & Generated Power(MWH) & $4 . E+06$ & 2.E+06 & 4. $E+12$ & 894105 & 8977154 \\
\hline \multirow{5}{*}{ All } & Effective Capacity (MW) & 563 & 504 & 254120 & 31 & 1843 \\
\hline & Fuel (Kilo Calorie) & 7.E+09 & 7.E+09 & $5 . E+19$ & 7.E+07 & $3 . E+10$ \\
\hline & Deviation From Generation plan (MWH) & 454 & 452 & 203913 & 42 & 4003 \\
\hline & Emission (Tones) & 2102367 & 2.E+06 & 4.E+12 & 19095 & 7976671 \\
\hline & Generated Power(MWH) & $3 . E+06$ & $3 . E+06$ & $9 . E+12$ & $8 . E+03$ & $1 . E+07$ \\
\hline
\end{tabular}

In Iran, 82.22\% of all government-owned installed capacity is using thermal technologies, of this

the shares of steam, gas, and combined cycle power plants are $29.68 \%, 24.66 \%$, and $27.79 \%$, respectively. Meanwhile, the rest of the government-owned installed capacity in 2010 came from $16.86 \%$ of hydro power plants and $0.99 \%$ of diesel and renewable energies power plants. Figure 2 shows the overall trend of the factors over the reference period. 

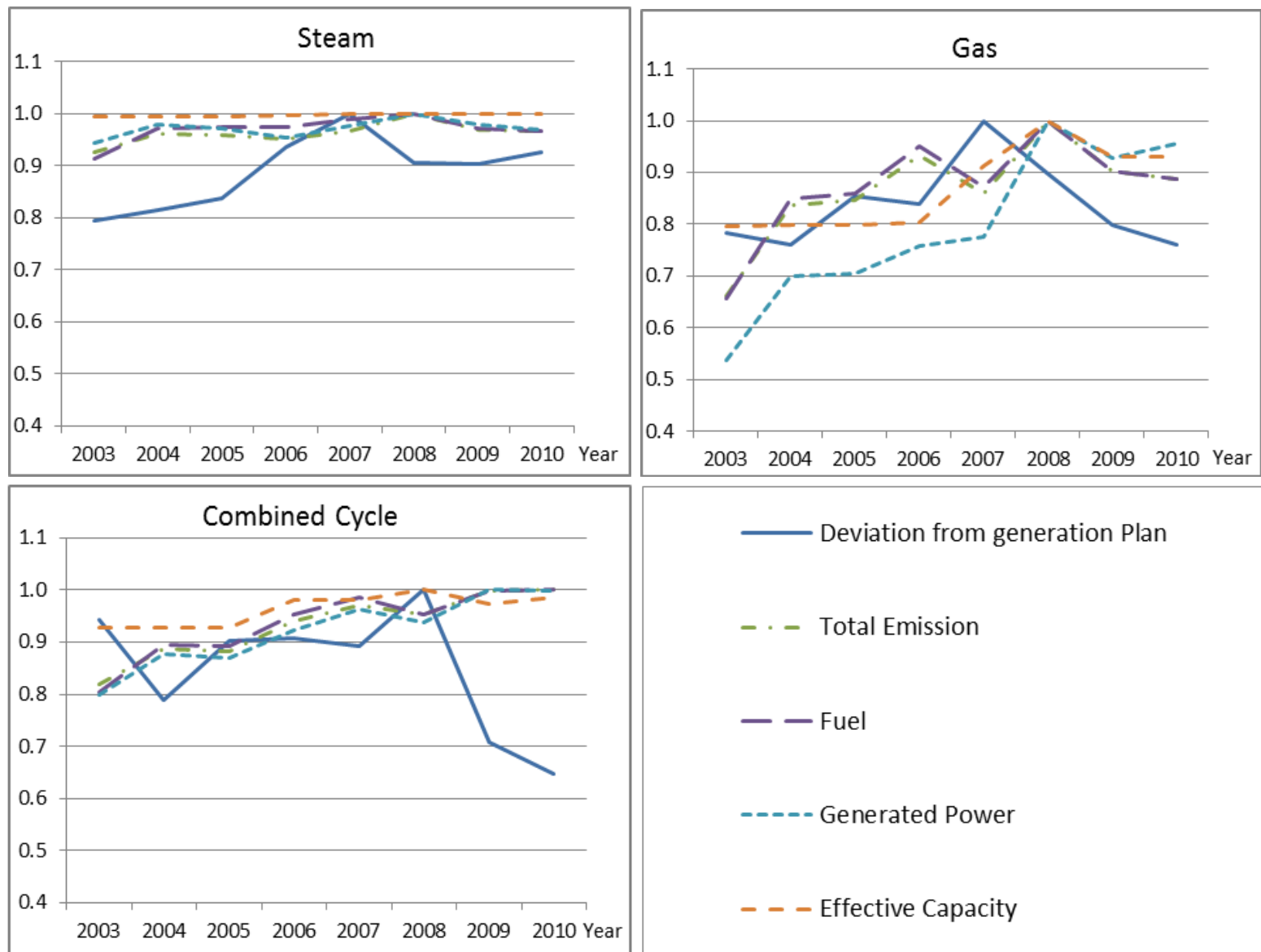

Figure 2: Aggregated Trend of Input and Output Factors in Three Categories of Thermal Power Plants

Figure 2 portrays the quantities of inputs used to generate the outputs by three different types of thermal power plants during 2003-2010. It should be noted that all values in Figure 2 have been normalized in order to be shown in a single graph; therefore the quantities are unitless. As can be seen in Figure 2, the deviation from generation plan for steam power plant has increased significantly from 2003 to 2007, but shows a clear decrease thereafter. The same pattern can be observed for combined cycle and gas power plants. This is because of the approbation of a new capacity payment instruction by Iran’s power market regulatory board in 2005.

The trend lines also show a drop in the fuel consumption and emission generated by the gas power plants from 2006 to 2007, which was accompanied by a small growth of yearly power generation. Recalling that February and March 2008 were the last two months in the Iranian 
calendar year, we can say Iran experienced a very cold winter during February and March 2008 and gas was the preferable heating source for households, while gas delivered to power plants had a lower quality in terms of heating value. In addition, during the winter months, gas power plants could not be started because of fuel shortage.

It can also be observed that all three types of the power plants experienced a peak for almost all factors in 2008. This can also be explained by the glacial winter of 2008. Winter is the season of hydration for dams, so the dispatching unit normally does not use hydroelectricity in the winter except for very urgent occasions, since the water must be stored for irrigation purposes for the coming summer. However, in the winter of 2008, since fuels including gas and gasoil were sent to households for heating purposes, deploying hydro power plants was inevitable for the dispatching to supply the electricity to the areas that faced a gas shortage and electricity could be used as an alternative for heating. Consequently, in the summer of the same year, the thermal power plants had to continue to supply electricity because the dams did not have enough water to generate hydroelectricity. This energy crisis had also caused the gas power plants to function as base load power plants instead of their usual use, where they are only deployed during peak hours or in emergencies due to their ability to turn on and shut down faster. The overuse of the thermal power plants had an adverse effect on their performance in the following years, which can be observed from the results in the next section.

\section{Results}

In this application, we employ the new slacks-based model, i.e. Model (5) to compute ML index, efficiency, and its counterpart - eco-efficiency (in fact ML index without emission has been taken as efficiency change) as well as the technology change of power plants over an 8-year period of Iran power industry restructuring. The model was implemented using the software 
AIMMS 3.11. The model was executed for the three types of thermal power plants that produce emissions, i.e. steam, gas, and combined cycle power plants. The results are presented in Table 5, 6 , and 7. The samples in this study consisted of 18 steam power plants, 19 gas power plants, and 10 combined cycle power plants.

Table 5: Results for Steam Power Plants

\begin{tabular}{|c|c|c|c|c|c|c|c|c|c|c|c|c|c|c|}
\hline \multirow{2}{*}{$\begin{array}{c}\text { Power } \\
\text { Plant } \\
\text { codes* }\end{array}$} & $\begin{array}{l}2003- \\
2004\end{array}$ & $\begin{array}{l}2004- \\
2005\end{array}$ & $\begin{array}{l}2005- \\
2006\end{array}$ & $\begin{array}{l}2006- \\
2007\end{array}$ & $\begin{array}{l}2007- \\
2008\end{array}$ & $\begin{array}{l}2008- \\
2009\end{array}$ & $\begin{array}{l}2009- \\
2010\end{array}$ & $\begin{array}{l}2003- \\
2004\end{array}$ & $\begin{array}{l}2004- \\
2005\end{array}$ & $\begin{array}{l}2005- \\
2006\end{array}$ & $\begin{array}{l}2006- \\
2007\end{array}$ & $\begin{array}{l}2007- \\
2008\end{array}$ & $\begin{array}{l}2008- \\
2009\end{array}$ & $\begin{array}{l}2009- \\
2010\end{array}$ \\
\hline & \multicolumn{7}{|c|}{ ML Index with Emissions } & \multicolumn{7}{|c|}{ ML Index without Emissions } \\
\hline St1 & 0.909 & 1.004 & 1.028 & 1.012 & 0.975 & 0.976 & 0.984 & 0.977 & 0.988 & 1.010 & 1.033 & 0.975 & 0.975 & 0.984 \\
\hline St2 & 0.938 & 1.043 & 0.953 & 1.048 & 1.047 & 0.971 & 1.001 & 0.945 & 1.025 & 0.967 & 1.024 & 1.041 & 0.949 & 1.011 \\
\hline St3 & 1.035 & 1.001 & 1.043 & 0.934 & 0.975 & 1.047 & 0.964 & 1.050 & 1.006 & 1.013 & 0.961 & 0.956 & 1.076 & 0.981 \\
\hline St4 & 1.045 & 0.828 & 0.988 & 1.018 & 1.007 & 1.256 & 0.883 & 1.020 & 0.935 & 0.963 & 1.018 & 1.009 & 1.131 & 0.939 \\
\hline St5 & 1.017 & 0.955 & 1.032 & 0.975 & 1.034 & 0.945 & 1.057 & 1.037 & 0.946 & 1.037 & 0.989 & 1.022 & 0.941 & 1.058 \\
\hline St6 & 1.006 & 0.997 & 0.995 & 1.006 & 0.985 & 0.996 & 0.997 & 1.005 & 0.998 & 0.995 & 1.005 & 0.946 & 0.996 & 0.998 \\
\hline St7 & 0.982 & 0.996 & 1.130 & 0.988 & 0.928 & 0.948 & 0.941 & 0.996 & 1.017 & 1.082 & 0.999 & 0.926 & 0.936 & 0.945 \\
\hline St8 & 0.962 & 1.021 & 0.959 & 0.957 & 1.011 & 0.969 & 0.988 & 0.974 & 1.039 & 0.918 & 1.007 & 1.012 & 0.982 & 0.955 \\
\hline St9 & 0.928 & 0.989 & 0.932 & 1.021 & 0.980 & 1.072 & 0.987 & 0.939 & 1.007 & 0.963 & 1.028 & 0.981 & 1.045 & 0.989 \\
\hline St10 & 0.999 & 1.026 & 0.987 & 1.004 & 1.025 & 0.971 & 1.005 & 0.990 & 1.065 & 0.963 & 1.004 & 1.036 & 0.966 & 1.001 \\
\hline St11 & 0.921 & 1.018 & 0.996 & 1.001 & 1.126 & 0.972 & 0.886 & 0.953 & 1.010 & 1.002 & 1.010 & 1.097 & 0.985 & 0.931 \\
\hline St12 & 1.008 & 1.009 & 0.953 & 0.999 & 0.998 & 0.982 & 1.028 & 1.005 & 1.006 & 0.976 & 0.995 & 1.010 & 0.977 & 1.010 \\
\hline St13 & 0.968 & 0.898 & 0.996 & 1.057 & 0.998 & 1.010 & 0.969 & 0.976 & 0.844 & 0.998 & 1.046 & 0.993 & 1.043 & 0.938 \\
\hline St14 & 1.051 & 0.768 & 0.871 & 1.454 & 1.066 & 0.909 & 1.016 & 1.052 & 0.925 & 0.910 & 1.171 & 1.040 & 0.952 & 1.017 \\
\hline St15 & 0.972 & 1.034 & 0.843 & 0.991 & 1.036 & 1.011 & 0.996 & 0.971 & 1.036 & 0.879 & 0.991 & 1.032 & 1.023 & 0.996 \\
\hline St16 & 1.008 & 0.991 & 0.985 & 0.981 & 1.082 & 0.993 & 0.999 & 1.013 & 0.981 & 0.989 & 0.976 & 1.075 & 0.995 & 0.986 \\
\hline St17 & 0.973 & 1.027 & 0.960 & 0.932 & 1.054 & 1.026 & 0.973 & 1.012 & 0.994 & 1.009 & 0.952 & 1.016 & 1.024 & 1.013 \\
\hline \multirow[t]{2}{*}{ St18 } & 1.045 & 0.952 & 1.043 & 0.974 & 1.034 & 1.001 & 0.995 & 1.022 & 0.955 & 1.019 & 1.000 & 1.014 & 1.002 & 0.996 \\
\hline & \multicolumn{7}{|c|}{ Eco-Efficiency Change } & \multicolumn{7}{|c|}{ Technology Change } \\
\hline St1 & 0.997 & 0.995 & 1.047 & 1.016 & 0.978 & 0.968 & 0.988 & 0.912 & 1.009 & 0.982 & 0.996 & 0.997 & 1.009 & 0.996 \\
\hline St2 & 0.955 & 1.014 & 0.979 & 1.022 & 1.029 & 0.960 & 1.001 & 0.982 & 1.029 & 0.973 & 1.025 & 1.018 & 1.012 & 1.000 \\
\hline St3 & 1.034 & 1.000 & 1.014 & 0.967 & 0.976 & 1.046 & 1.008 & 1.001 & 1.001 & 1.029 & 0.966 & 0.999 & 1.002 & 0.957 \\
\hline St4 & 1.000 & 0.948 & 0.998 & 1.020 & 1.009 & 1.028 & 1.000 & 1.045 & 0.874 & 0.990 & 0.998 & 0.998 & 1.222 & 0.883 \\
\hline St5 & 1.010 & 0.953 & 1.045 & 0.981 & 1.036 & 0.929 & 1.066 & 1.007 & 1.002 & 0.987 & 0.994 & 0.998 & 1.017 & 0.992 \\
\hline St6 & 0.979 & 1.007 & 1.022 & 0.982 & 1.031 & 1.015 & 1.014 & 1.028 & 0.990 & 0.974 & 1.024 & 0.955 & 0.982 & 0.983 \\
\hline St7 & 0.983 & 0.994 & 1.112 & 1.000 & 0.903 & 0.945 & 1.032 & 0.999 & 1.002 & 1.016 & 0.988 & 1.029 & 1.004 & 0.912 \\
\hline St8 & 0.979 & 1.029 & 0.923 & 1.009 & 1.003 & 1.018 & 0.992 & 0.982 & 0.992 & 1.039 & 0.948 & 1.007 & 0.952 & 0.996 \\
\hline St9 & 0.941 & 0.982 & 1.025 & 1.023 & 0.990 & 1.019 & 0.995 & 0.986 & 1.008 & 0.909 & 0.998 & 0.990 & 1.053 & 0.992 \\
\hline St10 & 1.001 & 1.021 & 0.996 & 1.006 & 1.027 & 0.960 & 1.011 & 0.998 & 1.005 & 0.991 & 0.998 & 0.998 & 1.011 & 0.994 \\
\hline St11 & 1.000 & 1.000 & 1.000 & 1.000 & 1.000 & 1.000 & 1.000 & 0.921 & 1.018 & 0.996 & 1.001 & 1.126 & 0.972 & 0.886 \\
\hline St12 & 1.000 & 1.000 & 1.000 & 1.000 & 1.000 & 0.964 & 1.038 & 1.008 & 1.009 & 0.953 & 0.999 & 0.998 & 1.019 & 0.991 \\
\hline St13 & 1.000 & 0.834 & 1.200 & 1.000 & 1.000 & 1.000 & 1.000 & 0.968 & 1.077 & 0.831 & 1.057 & 0.998 & 1.010 & 0.969 \\
\hline St14 & 1.067 & 0.893 & 1.031 & 1.086 & 1.000 & 0.902 & 1.034 & 0.985 & 0.860 & 0.845 & 1.338 & 1.066 & 1.007 & 0.983 \\
\hline St15 & 1.000 & 1.000 & 0.959 & 1.022 & 1.021 & 0.983 & 1.017 & 0.972 & 1.034 & 0.879 & 0.970 & 1.015 & 1.029 & 0.979 \\
\hline St16 & 1.002 & 0.979 & 1.007 & 0.984 & 1.040 & 0.979 & 1.006 & 1.007 & 1.012 & 0.978 & 0.996 & 1.041 & 1.015 & 0.993 \\
\hline St17 & 1.000 & 0.976 & 1.011 & 0.983 & 1.007 & 1.015 & 1.011 & 0.973 & 1.051 & 0.950 & 0.948 & 1.047 & 1.011 & 0.962 \\
\hline St18 & 1.018 & 0.977 & 1.016 & 1.001 & 1.010 & 1.000 & 0.992 & 1.027 & 0.975 & 1.027 & 0.973 & 1.024 & 1.001 & 1.003 \\
\hline $\begin{array}{l}\text { Corre- } \\
\text { lation }\end{array}$ & 0.8787 & 0.7494 & 0.9148 & 0.9509 & 0.9439 & 0.9056 & 0.8469 & & & & & & & \\
\hline
\end{tabular}

For confidentiality purposes, power plant names have been encoded

In Table 5-7, the value of ML index or any of its components that is greater than one denotes progress or improvement in performance, whereas values less than one denote deterioration in the relevant performance. Values of one reflect no change in performance. We may recall that 
the ML index is deployed when undesirable outputs are present. Therefore, in this research, we incorporate two types of undesirable outputs, i.e., emissions and deviation from generation plan.

The ML index results on the left section of the tables include emissions while the right section does not account for emissions but maintains all the other input-output factors. The correlation coefficient between the ML index estimates from the models with and without the emission factor for each period is listed in the last row of Tables 5-7.

Table 6: Results for Gas Power Plants

\begin{tabular}{|c|c|c|c|c|c|c|c|c|c|c|c|c|c|c|}
\hline \multirow{2}{*}{$\begin{array}{l}\text { Power } \\
\text { Plant } \\
\text { codes }\end{array}$} & $\begin{array}{l}2003- \\
2004\end{array}$ & $\begin{array}{c}2004- \\
2005\end{array}$ & $\begin{array}{l}2005- \\
2006\end{array}$ & $\begin{array}{l}2006- \\
2007\end{array}$ & $\begin{array}{l}2007- \\
2008\end{array}$ & $\begin{array}{c}2008- \\
2009\end{array}$ & $\begin{array}{l}2009- \\
2010\end{array}$ & $\begin{array}{l}2003- \\
2004\end{array}$ & $\begin{array}{c}2004- \\
2005\end{array}$ & $\begin{array}{l}2005- \\
2006\end{array}$ & $\begin{array}{l}2006- \\
2007\end{array}$ & $\begin{array}{c}2007- \\
2008\end{array}$ & $\begin{array}{c}2008- \\
2009\end{array}$ & $\begin{array}{l}2009- \\
2010\end{array}$ \\
\hline & \multicolumn{7}{|c|}{ Malmquist-Luenberger Index with Emission } & \multicolumn{7}{|c|}{ Malmquist-Luenberger Index without Emission } \\
\hline G1 & 1.072 & 0.881 & 1.635 & 0.629 & 1.015 & 0.867 & 0.990 & 0.989 & 0.922 & 1.533 & 0.690 & 1.368 & 0.457 & 0.781 \\
\hline $\mathrm{G} 2$ & 1.128 & 1.085 & 0.928 & 0.982 & 1.186 & 1.272 & 0.826 & 0.454 & 1.617 & 0.908 & 0.870 & 1.785 & 2.700 & 0.407 \\
\hline G3 & 0.970 & 1.192 & 0.859 & 0.885 & 1.257 & 1.071 & 0.895 & 0.940 & 1.227 & 0.871 & 0.868 & 1.196 & 1.068 & 0.746 \\
\hline G4 & 1.153 & 0.793 & 1.323 & 0.831 & 0.961 & 1.414 & 1.017 & 1.099 & 0.695 & 1.541 & 1.025 & 0.698 & 1.794 & 0.980 \\
\hline G5 & 1.121 & 1.012 & 1.031 & 0.849 & 1.075 & 1.318 & 0.884 & 1.055 & 1.077 & 0.926 & 0.915 & 1.012 & 1.473 & 0.739 \\
\hline G6 & 1.080 & 0.955 & 1.072 & 0.973 & 0.956 & 1.012 & 1.012 & 1.036 & 0.970 & 1.049 & 1.043 & 0.786 & 1.123 & 1.011 \\
\hline G7 & 1.116 & 1.103 & 0.793 & 1.170 & 1.008 & 1.161 & 0.954 & 1.078 & 1.092 & 0.781 & 1.100 & 1.130 & 1.146 & 0.750 \\
\hline G8 & 0.640 & 1.254 & 1.288 & 0.782 & 0.556 & 1.433 & 1.070 & 0.722 & 1.072 & 1.222 & 0.904 & 0.697 & 1.378 & 1.068 \\
\hline G9 & 1.465 & 0.334 & 0.770 & 2.609 & 1.688 & 1.162 & 1.486 & 1.196 & 0.663 & 0.790 & 2.181 & 1.481 & 1.139 & 1.223 \\
\hline G10 & 0.928 & 0.821 & 0.822 & 1.557 & 1.795 & 0.705 & 2.032 & 1.503 & 0.560 & 0.556 & 3.436 & 2.504 & 0.161 & 1.849 \\
\hline G11 & 1.243 & 1.063 & 0.880 & 0.912 & 1.284 & 1.118 & 1.269 & 0.747 & 1.185 & 0.747 & 0.746 & 2.130 & 1.409 & 2.301 \\
\hline G12 & 1.048 & 0.977 & 1.025 & 1.012 & 0.940 & 1.205 & 1.074 & 1.097 & 0.997 & 1.163 & 0.924 & 0.763 & 1.794 & 0.956 \\
\hline G13 & 0.994 & 0.927 & 1.090 & 0.973 & 0.930 & 1.216 & 1.037 & 0.999 & 0.838 & 1.369 & 0.852 & 0.821 & 2.227 & 1.154 \\
\hline G14 & 1.831 & 1.623 & 0.098 & 2.717 & 0.463 & 1.605 & 1.277 & 1.358 & 1.425 & 0.281 & 3.927 & 0.415 & 1.465 & 1.201 \\
\hline G15 & 0.666 & 0.805 & 1.085 & 0.821 & 1.609 & 1.139 & 0.822 & 0.344 & 0.682 & 1.231 & 0.930 & 2.704 & 1.354 & 0.460 \\
\hline G16 & 1.033 & 0.817 & 1.345 & 0.834 & 0.975 & 0.907 & 1.095 & 1.164 & 1.043 & 1.209 & 0.832 & 0.672 & 1.082 & 1.326 \\
\hline G17 & 0.990 & 1.175 & 0.838 & 0.980 & 0.952 & 1.032 & 0.944 & 0.948 & 1.113 & 0.724 & 1.217 & 0.922 & 1.175 & 0.901 \\
\hline G18 & 1.153 & 0.966 & 1.121 & 0.905 & 1.104 & 0.946 & 0.993 & 1.397 & 0.974 & 1.066 & 0.862 & 1.212 & 0.954 & 1.020 \\
\hline \multirow{2}{*}{ G19 } & 0.777 & 1.264 & 0.827 & 0.706 & 0.879 & 1.032 & 1.391 & 0.723 & 1.036 & 0.830 & 0.961 & 0.801 & 1.115 & 1.669 \\
\hline & \multicolumn{7}{|c|}{ Eco-Efficiency Change } & \multicolumn{7}{|c|}{ Technology Change } \\
\hline G1 & 1.010 & 1.000 & 1.000 & 0.927 & 0.990 & 0.966 & 0.997 & 1.007 & 0.969 & 1.131 & 0.961 & 1.013 & 0.999 & 1.001 \\
\hline $\mathrm{G} 2$ & 1.031 & 1.021 & 0.981 & 0.995 & 1.043 & 1.062 & 0.953 & 1.000 & 0.999 & 1.000 & 1.000 & 1.000 & 1.000 & 1.000 \\
\hline G3 & 0.989 & 1.050 & 0.959 & 0.966 & 1.057 & 1.017 & 0.973 & 1.003 & 0.995 & 1.004 & 1.004 & 1.001 & 1.000 & 1.000 \\
\hline G4 & 1.036 & 0.945 & 1.071 & 0.953 & 0.989 & 1.091 & 1.004 & 1.000 & 0.999 & 1.001 & 1.002 & 1.001 & 1.000 & 1.000 \\
\hline G5 & 1.029 & 1.003 & 1.007 & 0.959 & 1.018 & 1.071 & 0.970 & 1.000 & 1.000 & 1.001 & 1.001 & 1.000 & 1.000 & 1.000 \\
\hline G6 & 1.019 & 0.989 & 1.017 & 0.992 & 0.988 & 1.003 & 1.003 & 1.000 & 0.999 & 1.001 & 1.001 & 1.001 & 1.000 & 1.000 \\
\hline G7 & 1.028 & 1.025 & 0.943 & 1.040 & 1.001 & 1.038 & 0.988 & 1.000 & 1.000 & 1.000 & 1.000 & 1.000 & 1.000 & 1.000 \\
\hline G8 & 0.913 & 0.943 & 1.161 & 1.000 & 0.885 & 1.082 & 0.953 & 0.979 & 1.122 & 0.918 & 0.940 & 0.975 & 1.011 & 1.067 \\
\hline G9 & 1.000 & 1.000 & 1.000 & 1.000 & 1.000 & 1.000 & 1.000 & 1.100 & 0.760 & 0.937 & 1.271 & 1.140 & 1.038 & 1.104 \\
\hline G10 & 0.921 & 1.012 & 0.959 & 0.973 & 1.062 & 0.920 & 1.176 & 1.066 & 0.940 & 0.993 & 1.148 & 1.090 & 0.996 & 1.015 \\
\hline G11 & 1.056 & 1.021 & 0.967 & 0.968 & 1.059 & 1.029 & 1.061 & 1.000 & 0.995 & 1.002 & 1.009 & 1.006 & 1.000 & 1.000 \\
\hline G12 & 1.012 & 1.003 & 1.003 & 0.984 & 0.976 & 1.048 & 1.018 & 1.000 & 0.991 & 1.004 & 1.019 & 1.009 & 0.999 & 1.000 \\
\hline G13 & 0.998 & 0.983 & 1.021 & 0.989 & 0.980 & 1.050 & 1.009 & 1.000 & 0.999 & 1.001 & 1.004 & 1.002 & 1.000 & 1.000 \\
\hline G14 & 1.000 & 1.000 & 1.000 & 1.000 & 1.000 & 1.000 & 1.000 & 1.163 & 1.129 & 0.560 & 1.284 & 0.825 & 1.126 & 1.063 \\
\hline G15 & 0.903 & 0.954 & 1.018 & 0.940 & 1.116 & 1.034 & 0.952 & 1.000 & 0.993 & 1.002 & 1.012 & 1.009 & 0.999 & 1.001 \\
\hline G16 & 1.008 & 0.953 & 1.076 & 0.949 & 0.991 & 0.976 & 1.023 & 1.000 & 0.998 & 1.001 & 1.006 & 1.003 & 1.000 & 1.000 \\
\hline G17 & 0.998 & 1.042 & 0.956 & 0.992 & 0.986 & 1.008 & 0.986 & 1.000 & 0.999 & 1.000 & 1.003 & 1.001 & 1.000 & 1.000 \\
\hline G18 & 1.036 & 0.994 & 1.028 & 0.970 & 1.022 & 0.986 & 0.998 & 1.000 & 0.997 & 1.001 & 1.006 & 1.003 & 1.000 & 1.000 \\
\hline G19 & 0.929 & 1.064 & 0.952 & 0.908 & 0.962 & 1.008 & 1.085 & 1.010 & 0.996 & 1.001 & 1.009 & 1.006 & 0.999 & 1.000 \\
\hline $\begin{array}{c}\text { Correl- } \\
\text { ation }\end{array}$ & 0.534 & 0.704 & 0.898 & 0.873 & 0.855 & 0.775 & 0.800 & & & & & & & \\
\hline
\end{tabular}

The trend of ML index is of interest but it does not show a robust trend of change in 
performance. This could be because of some limitations in the power generation process, such as periodical maintenance, the overhaul programme, limitations in fuel supply, and the quality of fuel (heating value) that mask the more complex underlying patterns in individual power plants.

Table 7: Results for Combined Cycle Power Plants

\begin{tabular}{|c|c|c|c|c|c|c|c|c|c|c|c|c|c|c|}
\hline \multirow{2}{*}{$\begin{array}{l}\text { Power } \\
\text { Plant } \\
\text { codes }\end{array}$} & $\begin{array}{c}2003- \\
2004\end{array}$ & $\begin{array}{c}2004- \\
2005\end{array}$ & $\begin{array}{c}2005- \\
2006\end{array}$ & $\begin{array}{c}2006- \\
2007\end{array}$ & $\begin{array}{c}2007- \\
2008\end{array}$ & $\begin{array}{c}2008- \\
2009\end{array}$ & $\begin{array}{c}2009- \\
2010\end{array}$ & $\begin{array}{c}2003- \\
2004\end{array}$ & $\begin{array}{c}2004- \\
2005 \\
\end{array}$ & $\begin{array}{c}2005- \\
2006\end{array}$ & $\begin{array}{c}2006- \\
2007\end{array}$ & $\begin{array}{c}2007- \\
2008\end{array}$ & $\begin{array}{c}2008- \\
2009\end{array}$ & $\begin{array}{c}2009- \\
2010\end{array}$ \\
\hline & \multicolumn{7}{|c|}{ Malmquist-Luenberger Index with Emission } & \multicolumn{7}{|c|}{ Malmquist-Luenberger Index without Emission } \\
\hline CC1 & 1.015 & 1.026 & 0.940 & 0.906 & 1.056 & 0.916 & 0.897 & 1.008 & 1.022 & 0.985 & 0.977 & 1.014 & 0.978 & 0.973 \\
\hline $\mathrm{CC} 2$ & 1.118 & 0.961 & 0.825 & 1.086 & 0.797 & 1.646 & 0.541 & 1.038 & 0.995 & 0.955 & 1.007 & 0.958 & 1.075 & 0.903 \\
\hline $\mathrm{CC} 3$ & 1.032 & 0.778 & 1.247 & 0.939 & 1.050 & 1.005 & 1.077 & 1.010 & 0.939 & 1.052 & 0.977 & 1.010 & 1.001 & 1.024 \\
\hline CC4 & 1.023 & 1.031 & 0.983 & 1.045 & 1.154 & 1.006 & 0.974 & 1.005 & 1.007 & 0.998 & 1.008 & 1.037 & 1.015 & 0.989 \\
\hline $\mathrm{CC} 5$ & 0.689 & 0.956 & 1.035 & 0.921 & 0.971 & 0.724 & 1.252 & 0.912 & 0.984 & 1.011 & 0.983 & 1.002 & 0.922 & 1.058 \\
\hline CC7 & 0.785 & 1.026 & 1.118 & 0.859 & 1.189 & 1.029 & 1.102 & 0.943 & 1.006 & 0.950 & 0.964 & 1.044 & 1.062 & 0.999 \\
\hline $\mathrm{CC} 8$ & 0.904 & 0.952 & 1.025 & 1.031 & 1.221 & 1.060 & 0.892 & 1.007 & 0.974 & 1.011 & 1.007 & 1.041 & 1.015 & 0.967 \\
\hline $\mathrm{CC9}$ & 1.046 & 0.628 & 1.352 & 0.585 & 1.097 & 1.252 & 0.984 & 1.014 & 0.941 & 1.011 & 0.902 & 1.022 & 1.030 & 0.997 \\
\hline \multirow[t]{2}{*}{ CC10 } & 0.950 & 0.995 & 0.701 & 1.025 & 1.005 & 0.996 & 0.882 & 0.933 & 1.006 & 0.914 & 1.014 & 0.957 & 0.997 & 1.024 \\
\hline & \multicolumn{7}{|c|}{ Eco-Efficiency Change } & \multicolumn{7}{|c|}{ Technology Change } \\
\hline $\mathrm{CC} 1$ & 1.000 & 1.000 & 1.000 & 1.000 & 1.000 & 1.000 & 1.000 & 1.004 & 1.007 & 0.985 & 0.976 & 1.014 & 0.978 & 0.973 \\
\hline $\mathrm{CC} 2$ & 1.041 & 1.000 & 0.980 & 1.020 & 0.953 & 1.049 & 0.968 & 0.988 & 0.990 & 0.972 & 1.001 & 0.991 & 1.080 & 0.886 \\
\hline $\mathrm{CC} 4$ & 1.055 & 0.967 & 1.031 & 0.995 & 1.036 & 0.993 & 1.003 & 0.953 & 1.042 & 0.965 & 1.016 & 1.001 & 1.009 & 0.990 \\
\hline CC5 & 1.108 & 1.061 & 0.944 & 1.089 & 0.913 & 1.009 & 1.122 & 0.822 & 0.932 & 1.069 & 0.900 & 1.087 & 0.914 & 0.943 \\
\hline CC6 & 1.000 & 0.917 & 1.020 & 1.045 & 1.023 & 1.000 & 0.949 & 0.959 & 0.997 & 0.954 & 0.952 & 0.987 & 1.062 & 0.982 \\
\hline $\mathrm{CC} 7$ & 1.095 & 1.010 & 0.955 & 1.081 & 1.023 & 1.001 & 1.011 & 0.860 & 0.997 & 1.077 & 0.891 & 1.020 & 1.006 & 1.014 \\
\hline $\mathrm{CC} 8$ & 1.011 & 0.975 & 1.013 & 1.014 & 1.054 & 0.974 & 0.977 & 0.965 & 1.013 & 0.993 & 0.993 & 0.997 & 1.042 & 0.995 \\
\hline $\mathrm{CC9}$ & 1.000 & 0.947 & 1.056 & 0.900 & 1.036 & 1.028 & 1.044 & 1.011 & 0.940 & 1.021 & 0.972 & 0.988 & 1.029 & 0.954 \\
\hline CC10 & 1.031 & 1.007 & 1.003 & 1.025 & 1.020 & 0.972 & 1.028 & 0.957 & 0.992 & 0.912 & 0.982 & 0.982 & 1.028 & 0.943 \\
\hline $\begin{array}{l}\text { Corre- } \\
\text { lation }\end{array}$ & 0.864 & 0.9143 & 0.683 & 0.984 & 0.869 & 0.862 & 0.902 & & & & & & & \\
\hline
\end{tabular}

Nevertheless, the kernel density plot can illustrate if the power plants in each category had an improvement in performance or otherwise. Figure 3 shows kernel density plot for three categories of the thermal power plants. ${ }^{19}$ Here, the skewness is positive for all the three types of power plants, presenting that most of the MLI's have a tendency to be more than one or suggesting that power plants have improved their eco-efficiencies over the period, albeit a marginal improvement with respect to combined cycle power plants.

\footnotetext{
${ }^{19}$ A kernel density plot helps making inferences about a finite data sample. This plot simply depicts the distribution pattern of a data sample around its mean.
} 

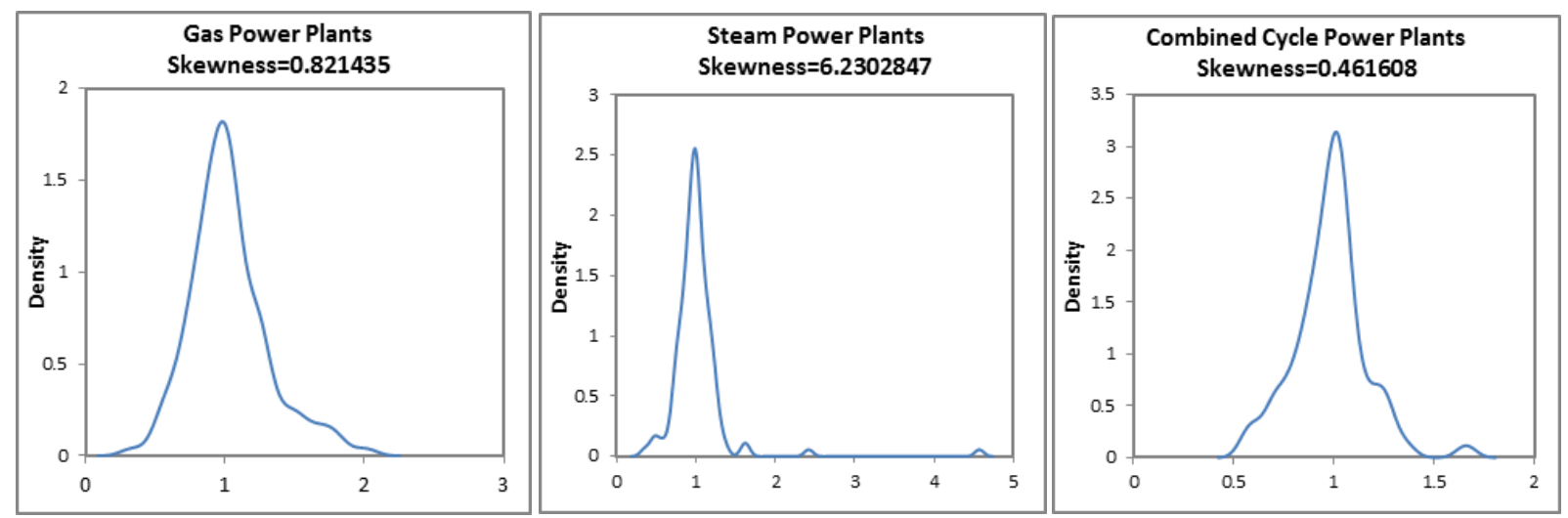

Figure 3: Kernel Density Plots for Three Categories of the Thermal Power Plants

In addition to above results and discussions, here we put forth an alternative approach to discover the underlying trend in the power plants performance. We use the ML index as the rate of change, and by including their effective capacity; we can calculate the aggregated rate of change for each period, $S_{M L}$, as follows:

Where:

$M L_{n}=$ ML index rate for $n^{\text {th }}$ power plant in a particular period

$\operatorname{PEFFCAP_{n}}=$ Effective Capacity for $n^{\text {th }}$ power plant in a particular period $S_{M L}=$ Aggregated Rate of Change of ML index by Effective Capacity

This index was introduced because the ML index for each power plant did not provide a clear general trend in the period 2003-2010. Note that the ML index is multiplied by effective capacity $\operatorname{PEFFCAP}_{n}$, since the rate of change itself is useless for comparative analyses unless the capacity is taken into account.

The aggregated rate of change for each period for the three types of power plants $S_{M L}$ is summarized in Table 8: 
Table 8: $S_{M L}$ Index Aggregate Rate of Change

\begin{tabular}{ccccc}
\hline \multirow{2}{*}{ Period } & \multicolumn{4}{c}{$S_{M L}$} \\
\cline { 2 - 5 } & Gas & Steam & $\begin{array}{c}\text { Combined } \\
\text { Cycle }\end{array}$ & Total \\
\hline $2003-2004$ & 0.0470 & -0.0208 & -0.0219 & 0.0043 \\
$2004-2005$ & -0.0260 & -0.0440 & -0.0297 & -0.0997 \\
$2005-2006$ & -0.1052 & -0.0371 & 0.0068 & -0.1355 \\
$2006-2007$ & 0.1157 & 0.0595 & -0.0168 & 0.1585 \\
$2007-2008$ & 0.0450 & 0.0311 & 0.0110 & 0.0872 \\
$2008-2009$ & 0.0090 & -0.0033 & 0.0117 & 0.0174 \\
$2009-2010$ & 0.0932 & -0.0207 & -0.0162 & 0.0564 \\
\hline
\end{tabular}

From Table 8, it may be seen that after an initial decline in performance in the immediate two to three years of restructuring, performance improved in the following years for all the three categories of power plants. It can also be observed that the rate of improvement declined tremendously in 2010, perhaps due to the overuse of power plants after a very cold winter in 2007. Overall, the results suggest that there has been an eco-efficiency improvement in the sector. At this point, it is worth mentioning that, although Figure 3 and Table 8 portray a general improvement in power plants eco-efficiency over the period, it is observed that amongst the individual combined cycle power plants, the largest plants have performed less efficiently, explaining the negative values of $S_{M L}$ for 4 out of 7 periods of the study.

In the next section, the results of the study are discussed in detail.

\section{Some observations and recommendations}

In this research, a new adopted model, Model (5) was put into practice and by observing the results from Table 5 to 8, reasonable results were obtained. According to Färe and Grosskopf (2010a; 2010b), where the Model (5) was adopted from, this model has critical advantages since it does not use an arbitrary direction. The model allows the unit to identify the direction so that it 
will be projected to the frontier via the farthest distance, while the good outputs are expanded and bad ones are contracted simultaneously. This will put the unit in the best light as well as provide targets that are easier for the unit to achieve in the short run. From this perspective, this new model can be deployed for eco-efficiency and ML index evaluation henceforth.

Furthermore, the last rows of Tables 5-7 indicate a high correlation between the ML index including and excluding emissions, with the only two exception of the combined cycle power plant over 2005-2006 and gas power plant over 2003-2004, which are only weakly correlated. This finding supports the controversial hypothesis about the positive relationship between efficiency and eco-efficiency in power generation industry. Based on what has been discussed before, environmental factors must be incorporated in the analyses of performance. It has been proven in many contexts that by incorporating environmental factors, the eco-efficiency has not dropped (Färe et al., 2007; Korhonen and Luptacik, 2004). In fact, in many cases including environmental factors, the performance management programme -- of course with a significant lag -- was associated with a drop in cost. However, in our case of the Iranian power plants, results show a close relationship between performance with and without emission factors. These results, which have been achieved for the first time in Iran, pave the way for further studies in this field in Iran.

In addition, Table 8 exhibits a critical result for Iran power industry restructuring. Although in the early three periods ML index shows a drop in general, in the next periods, especially for the steam and gas power plants, it shows a clear growth. However, this growth is not so apparent for the combined cycle power plants. This could be due to several reasons. First, combined cycle power plants are deployed continuously as base load supplier since they are mostly high capacity and their minimum up and down time are so long. Therefore, since the combined cycle plants 
performance completely depends on optimum operation and maintenance plan, they did not receive their periodical maintenance and overhaul, as they had to supply energy for long periods because hydro power plants could not supply electricity long after the glacial 2007 winter. Second, fuel quality and supply have not been steady and in many cases, the power plants have had to use their second or third types of the fuel, which are gas oil and fuel oil a decrease in the turbines efficiency and a rise in the emission production. Finally, as can be seen from Table 8, the overall rate of $S_{M L}$ index growth for all the power plants is positive; regardless of the initial regress in eco-efficiency due to the shock in the first few years of restructuring. Taking into account the results displayed in Table 8 as well Figure 3, it can be concluded that in the 8-year period of restructuring in Iran's power industry, the thermal power plants eco-efficiency improved in general.

To summarize, it can be concluded that restructuring of the Iranian power industry succeeded in attaining its first and foremost objective, which is improving power generation facilities performance. Simultaneously, emissions were held and the eco-efficiency improved. This restructuring has forced power plants to be more conservative on their prices and consumption. These all have contributed to a series of alterations in performance via regular and careful maintenance programs, and in some cases renovation of technology. This lights the path for restructuring leaders to continue their efforts in sustainable development. In addition, the results of this study do not only provide a general overview for the power plants, which are owned by the Government that oversees their operation, but they are also useful in helping the private sector to take a proper power plant to purchase, as the power industry reform involves privatization. 


\section{Conclusion}

In this paper, a new slacks-based model for measuring Malmquist-Luenberger (ML) productivity index was introduced. Unlike the previous Directional Distance Function (DDF) type models, the proposed one does not use arbitrary directions; instead, the model employs the directions that were endogenously obtained. These directions let the model find a more realistic value of ecoefficiency for each inefficient DMU. The new model can be deployed in different polluting industries for measuring eco-efficiency; in this paper it has been successfully used to calculate the ML index, efficiency, and its counterpart - eco-efficiency, and technological change in the Iranian thermal power plants over the 8-year period of restructuring. The results revealed that eco-efficiency of power plants had a positive trend with a strong relationship between power plant efficiency and eco-efficiency from 2003 to 2010. It should be noted that due to heterogeneity amongst thermal power plant technologies, we had to consider three different frontiers. Researchers interested may extend the proposed model to a meta-frontier technology and replicate the analysis using a pooled data.

\section{Acknowledgment}

The authors would like to extend their appreciations to Professor Lorna A. Greening, the editor of Energy Policy, and two anonymous reviewers whose constructive comments and valuable insights substantially improved the quality of the paper.

\section{References}

Alirezaee, M. R. (2005). The overall assurance interval for the non-Archimedean Epsilon in DEA models; a partition base algorithm. Applied Mathematics and Computation, 164(3), 667- 
674.

Athanassopoulos, A. D., Lambroukos, N., Seiford, L. (1999). Data envelopment scenario analysis for setting targets to electricity generating plants. European journal of operational research, 115(3), 413-428.

Azadeh, A., Ghaderi, S. F., Anvari, M., Saberi, M. (2007). Performance assessment of electric power generations using an adaptive neural network algorithm. Energy Policy, 35(6), 3155-3166.

Azadeh, A., Ghaderi, S. F., Maghsoudi, A. (2008). Location optimization of solar plants by an integrated hierarchical DEA PCA approach. Energy Policy, 36(10), 3993-4004.

Azadeh, A., Ghaderi, S. F., Omrani, H., Eivazy, H. (2009). An integrated DEA-COLS-SFA algorithm for optimization and policy making of electricity distribution units. Energy Policy, 37(7), 2605-2618.

Bennett, M., Bouma, J., Wolters, T. (2004). The development of environmental management accounting: general introduction and critical review. Environmental Management Accounting: Informational and Institutional Developments, 1-18.

Berg, S. A., Førsund, F. R., Jansen, E. S. (1992). Malmquist indices of productivity growth during the deregulation of Norwegian banking, 1980-89. The Scandinavian Journal of Economics, 94, 211-228.

Boyd, G. A., McClelland, J. D. (1999). The Impact of Environmental Constraints on Productivity Improvement in Integrated Paper Plants. Journal of Environmental Economics and Management, 38(2), 121-142.

Brundtland, G. (1987). Our Common Future: The World Commission on Environment and 
Development: Oxford University Press, Oxford.

Bulent Tor, O., Shahidehpour, M. (2005, 12-16 June 2005). Electric power restructuring in Turkey. Paper presented at the Power Engineering Society General Meeting, 2005. IEEE.

Burnett, R. D., Hansen, D. R. (2008). Ecoefficiency: Defining a role for environmental cost management. Accounting, Organizations and Society, 33(6), 551-581.

Burritt, R., Hahn, T., Schaltegger, S. (2004). An Integrative Framework of Environmental Management Accounting-Consolidating the Different Approaches of EMA into a Common Framework and Terminology. Environmental Management Accounting: Informational and Institutional Developments, 21-35.

Charnes, A. (1994). Data envelopment analysis: theory, methodology, and application: Springer.

Charnes, A., Cooper, W., Rhodes, E. (1978). Measuring the efficiency of decision making units. European journal of operational research, 2(6), 429-444.

Chitkara, P. (1999). A data envelopment analysis approach to evaluation of operational inefficiencies in power generating units: a case study of Indian power plants. Power Systems, IEEE Transactions on, 14(2), 419-425.

Chung, Y. H., Färe, R., Grosskopf, S. (1997). Productivity and Undesirable Outputs: A Directional Distance Function Approach. Journal of Environmental Management, 51(3), 229240.

Cronin, F. J., Motluk, S. A. (2006). Reviewing electric distribution restructuring in Ontario: policy without substance or commitment. Utilities Policy, 14(1), 1-7. 
Eybalin, A., Shahidehpour, M. (2003). Electricity restructuring in France. Paper presented at the Power Engineering Society General Meeting, 2003, IEEE.

Färe, R., Grosskopf, S. (2010a). Directional distance functions and slacks-based measures of efficiency. European journal of operational research, 200(1), 320-322.

Färe, R., Grosskopf, S. (2010b). Directional distance functions and slacks-based measures of efficiency: Some clarifications. European journal of operational research, 206(3), 702.

Färe, R., Grosskopf, S., Noh, D. W., Weber, W. (2005). Characteristics of a polluting technology: theory and practice. Journal of Econometrics, 126(2), 469-492.

Färe, R., Grosskopf, S., Norris, M., Zhang, Z. (1994). Productivity growth, technical progress, and efficiency change in industrialized countries. The American Economic Review, 66-83.

Färe, R., Grosskopf, S., Pasurka, J. C. A. (2007). Environmental production functions and environmental directional distance functions. Energy, 32(7), 1055-1066.

Färe, R., Grosskopf, S., Pasurka Jr, C. A. (2001). Accounting for air pollution emissions in measures of state manufacturing productivity growth. Journal of Regional Science, 41(3), 381409.

Farrell, M. J. (1957). The measurement of productive efficiency. Journal of the Royal Statistical Society. Series A (General), 120(3), 253-290.

Ghazizadeh, M. S., Sheikh-El-Eslami, M. K., Seifi, H. (2007). Electricity restructuring [Business Scene]. Power and Energy Magazine, IEEE, 5(2), 16-20.

Golany, B., Roll, Y., Rybak, D. (1994). Measuring efficiency of power plants in Israel by data 
envelopment analysis. Engineering Management, IEEE Transactions on, 41(3), 291-301.

Goto, M., Tsutsui, M. (1998). Comparison of productive and cost efficiencies among Japanese and US electric utilities. Omega, 26(2), 177-194.

Hansen, U. (1996). Restructuring the East German energy system. Energy Policy, 24(6), 553562.

Hasna, A. M. (2007). Dimensions of sustainability. Journal of Engineering for Sustainable Development: Energy, Environment, and Health, 2(1), 47-57.

Huppes, G., Ishikawa, M. (2007). An introduction to quantified eco-efficiency analysis. Quantified Eco-Efficiency, 1-38.

Jan, B., Rob, G., David, O. (1999). Seeing the wood for the trees: Taking the pulse of social and environmental accounting. [DOI: 10.1108/09513579910259906]. Accounting, Auditing \& Accountability Journal, 12(1), 47-52.

Jasch, C. (2004). Environmental management accounting metrics: procedures and principles. Environmental Management Accounting: Informational and Institutional Developments, 37-50.

Jha, D. K., Shrestha, R. (2006). Measuring efficiency of hydropower plants in Nepal using data envelopment analysis. Power Systems, IEEE Transactions on, 21(4), 1502-1511.

Karbassi, A., Abduli, M., Mahin Abdollahzadeh, E. (2007). Sustainability of energy production and use in Iran. Energy Policy, 35(10), 5171-5180.

Kern, F., Smith, A. (2008). Restructuring energy systems for sustainability? Energy transition policy in the Netherlands. Energy Policy, 36(11), 4093-4103. 
Khosroshahi, K. A., Jadid, S., Shahidehpour, M. (2009). Electric Power Restructuring in Iran: Achievements and Challenges. The Electricity Journal, 22(2), 74-83.

Kim, J. D. (2004). A guideline for the measurement and reporting of environmental costs. Environmental Management Accounting: Informational and Institutional Developments, 51-65.

Knox Lovell, C. A., Pastor, J. T., Turner, J. A. (1995). Measuring macroeconomic performance in the OECD: A comparison of European and non-European countries. European journal of operational research, 87(3), 507-518.

Koopmans, T. C. (1951). Analysis of production as an efficient combination of activities. Activity analysis of production and allocation, 13, 33-37.

Korhonen, P. J., Luptacik, M. (2004). Eco-efficiency analysis of power plants: An extension of data envelopment analysis. European journal of operational research, 154(2), 437-446.

Mazandarani, A., Mahlia, T., Chong, W., Moghavvemi, M. (2010). A review on the pattern of electricity generation and emission in Iran from 1967 to 2008. Renewable and Sustainable Energy Reviews, 14(7), 1814-1829.

Mazandarani, A., Mahlia, T. M. I., Chong, W. T., Moghavvemi, M. (2011). Fuel consumption and emission prediction by Iranian power plants until 2025. Renewable and Sustainable Energy Reviews, 15(3), 1575-1592.

Oggioni, G., Riccardi, R., Toninelli, R. (2011). Eco-efficiency of the world cement industry: A data envelopment analysis. Energy Policy, 39(5), 2842-2854.

Oude Lansink, A., Bezlepkin, I. (2003). The effect of heating technologies on CO2 and energy efficiency of Dutch greenhouse firms. Journal of Environmental Management, 68(1), 73-82. 
Picazo-Tadeo, A. J., Gómez-Limón, J. A., Reig-Martínez, E. (2011). Assessing farming ecoefficiency: A Data Envelopment Analysis approach. Journal of Environmental Management, 92(4), 1154-1164.

Picazo-Tadeo, A. J., Reig-Martínez, E., Hernández-Sancho, F. (2005). Directional distance functions and environmental regulation. Resource and Energy Economics, 27(2), 131-142.

Rudnick, H., Barroso, L. A., Skerk, C., Blanco, A. (2005). South American reform lessons twenty years of restructuring and reform in Argentina, Brazil, and Chile. Power and Energy Magazine, IEEE, 3(4), 49-59.

Sarica, K., Or, I. (2007). Efficiency assessment of Turkish power plants using data envelopment analysis. Energy, 32(8), 1484-1499.

Schaltegger, S., Bennett, M., Burritt, R. L. (2008). Environmental management accounting for cleaner production: Springer Verlag.

Scheel, H. (2001). Undesirable outputs in efficiency valuations. European journal of operational research, 132(2), 400-410.

Shanmugam, K., Kulshreshtha, P. (2005). Efficiency analysis of coal-based thermal power generation in India during post-reform era. International journal of global energy issues, 23(1), $15-28$.

Sharabaroff, A., Boyd, R., Chimeli, A. (2009). The environmental and efficiency effects of restructuring on the electric power sector in the United States: An empirical analysis. Energy Policy, 37(11), 4884-4893.

Stagliano, V. (1997). Restructuring, the New England way. The Electricity Journal, 10(6), 21-27. 
Sueyoshi, T., Goto, M. (2011). DEA approach for unified efficiency measurement: Assessment of Japanese fossil fuel power generation. Energy Economics, 33(2), 292-303.

Tone, K. (2001). A slacks-based measure of efficiency in data envelopment analysis. European journal of operational research, 130(3), 498-509.

Tor, O. B. (2005). Electricity restructuring in turkey: promises and predicaments. Power and Energy Magazine, IEEE, 3(3), 25-29.

Tyteca, D. (1997). Linear programming models for the measurement of environmental performance of firms-concepts and empirical results. Journal of productivity analysis, 8(2), 183-197.

Viljainen, S., Partanen, J. (2005). Development trends in the restructuring of the electricity distribution business in Finland. Paper presented at the Power Tech, 2005 IEEE Russia.

Walls, W. D., Rusco, F. W., Ludwigson, J. (2007). Power plant investment in restructured markets. Energy, 32(8), 1403-1413.

Welch, E., Barnum, D. (2009). Joint environmental and cost efficiency analysis of electricity generation. Ecological Economics, 68(8-9), 2336-2343.

Wiser, R., Pickle, S., Goldman, C. (1998). Renewable energy policy and electricity restructuring: a California case study. Energy Policy, 26(6), 465-475.

Yaisawarng, S., Klein, J. D. (1994). The Effects of Sulfur Dioxide Controls on Productivity Change in the U.S. Electric Power Industry. The Review of Economics and Statistics, 76(3), 447460. 
Yang, H., Pollitt, M. (2009). Incorporating both undesirable outputs and uncontrollable variables into DEA: The performance of Chinese coal-fired power plants. European journal of operational research, 197(3), 1095-1105.

Yang, H., Pollitt, M. (2010). The necessity of distinguishing weak and strong disposability among undesirable outputs in DEA: Environmental performance of Chinese coal-fired power plants. Energy Policy, 38(8), 4440-4444.

Yeh, Q. J. (1996). The application of data envelopment analysis in conjunction with financial ratios for bank performance evaluation. Journal of the operational Research Society, 980-988.

Zaim, O., Taskin, F. (2000). Environmental efficiency in carbon dioxide emissions in the OECD: A non-parametric approach. Journal of Environmental Management, 58(2), 95-107.

Zhang, B., Bi, J., Fan, Z., Yuan, Z., Ge, J. (2008). Eco-efficiency analysis of industrial system in China: A data envelopment analysis approach. Ecological Economics, 68(1-2), 306-316.

Zhou, P., Ang, B. W., Poh, K. L. (2006). Slacks-based efficiency measures for modeling environmental performance. Ecological Economics, 60(1), 111-118.

Zhou, P., Poh, K. L., Ang, B. W. (2007). A non-radial DEA approach to measuring environmental performance. European journal of operational research, 178(1), 1-9. 